\title{
Notes
}

\section{The Ins and Outs of IATA: Improving the Role of the United States in the Regulation of International Air Fares}

It is a settled principle of international law that the sovereignty of a state extends throughout the airspace directly above its territory. ${ }^{1}$ in the exercise of this sovereignty one of the conditions commonly imposed upon the operating rights of foreign aircraft is that for commercial flights, these aircraft must charge fares acceptable to the host coun-

1. B. Cheng, The Law of International Air Transport 3 (1962); M. McDougal, H. Lasswell \& I. Vlasic, LAw and Public ORder in SPACE 254 (1963). See generally W. Wati* NER, INternational AIR Transportation as Affected bY State Sovereignty (Brisscls 1970 ).

The principle of state sovereignty over the airspace above national territories was ex. tensively debated prior to World War One. At this time the French were the principal advocates of "freedom of the air," with Great Britain the leading spokcsman for air sovereignty. Even at this early stage of aeronautical development, proponents of "freclom of the air" bore the burden of persuasion in the debate. Implicit in efforts to achicve in. ternational agreement on freedom of the air was the notion that there was some sort of existing sovereign authority over national airspace which, until relinguished, would allow a state to exclude foreign aircraft from its airspace. Thus an International Con. ference on Air Navigation was convened at Paris in 1910 in the hope that it would lead to a convention giving air transport the international rights of access then desired by the French. After the Paris Conference foundered on the sovereignty issue, European states, including France, began explicitly to assert sovereignty over national airspace. S'c' $L^{\prime}$. Tombs, International Organization in European Air Transport 4.6 (1936); C. Cilkistol, Transit bY AIR in International Law 72-74 (1944). Following the First World Watr, the countries of continental Europe wanted no part of "freedom of the air." The British reversed their earlier position but now found no support for proposals to limit air sov. creignty. The Paris Peace Conference ultimately gave rise to the first multilateral proclat. mation of the principle of air sovereignty, the Convention for the Regulation of $A$ crial Navigation, Oct. 13, 1919, [1922] G.B.T.S. No. 2, 11 L.N.T.S. 173. See O. Lissirz1N, INTtknational Air Transport and National Policy 366 (1942).

Although the United States was a signatory, the United States did not ratify the laris Convention. The first official assertion of the United States' sovereignty over its airspace came in the Air Commerce Act of 1926, \$ 6(a), ch. 344, \$ 6(a), 44 Stat. 572 (rcpealcd 1958) The first multilateral affirmation of the principle of air sovereignty which the United States did ratify was the Pan American Convention for Commercial Air Navigation, Feb. 20, 1928, 47 Stat. 1901 (1933), T.S. No. 840. The latest multilateral convention ratificd by the United States which is declarative of air sovereignty is the Convention on Inter. national Civil Aviation, Dec. 7, 1944, 61 Stat. 1180 (1948), T.I.A.S. No. 1591. The Federal Aviation Act of 1958, 49 U.S.C. $\$ \S 1301$ ff. (1970) (originally cnacted as Pub. L. No. 85.726 , 72 Stat. 731), re-enacted the Air Commerce Act's declaration of air sovercignty as 1108 (a), 72 Stat. 798, 49 U.S.C. $\$ 1508$ (a) (1970).

The settled international law of national sovereignty over airspace should not bc con. fused with the much less certain rights of a state regarding the outer space above its territory. See generally J. COOPER, EXPLORATIONS IN AEROSIACE LAw (1. Vlasic ed. 1968); M. McDougat, ET AL., supra. For the difficulties in distinguishing between airspace and outer space, see M. MCDougAL, ET AL., id., at 33-35, 244. 
try. Disputes as to the proper fares to be charged for such flights have been resolved through an international legal process, under which the great majority of the world's scheduled international air carriers determine their own rates. These airlines negotiate tariff agreements which fix the price of air travel on most internaional routes. The central institution of this system is the International Air Transport Association (IATA). ${ }^{2}$

In recent months, the instability of IATA tariff agreements and the inability of IATA to arrive expeditiously at new tariff agreements have led to speculation that IATA may be on the verge of internal collapse. ${ }^{3}$ Heartened by such a prospect are the consumer advocates who have long attacked IATA as a cartel dedicated to the preservation of artificially high fares at the expense of the travelling public. Yet both the prophets and the proponents of IATA's demise have failed to consider adequately whether all forms of regulation of air faires can be avoided, and if not, what sort of alternative regulatory apparatus would be more desirable than IATA:

This Note accepts the present international legal process for regulat-

2. In 1970 IATA airlines carried 89.2 per cent of total world scheduled traffic, flew 87.I per cent of the world's scheduled passenger-kilometers and 93.2 per cent of world scheduled freight ton-kilometers. As of Nov. 18, 1971, there vere ninety active member airlines of IATA and sixteen associate member airlines. 39 LATA BuLL. 60, 128.29 (1971).

3. For reports of IATA's problems in the summer and fall of 1971 , see N.Y. Times, June 1, 1971, at 1 , col. 1; id., June 4, 1971, at 70, col. 7 ; id., June 5 , 1971. at 57, col. 3; Wall St. J., June 9, 1971, at 23, col. 3; N.Y. Times, June 11, 1971, at 1, col. 6; id., June 12, 1971, at 1, col. 4; id., June 15, 1971, at 85, col. 1; Wall St. J., June 15, 1971, at 14, col. 4 ; $i d$. , June 16, 1971, at 34 , col. 1 ; $i d$., June 17,1971 , at 6 , col. $2 ;$ id., June 18 , 1971, at 7 , col. 3; N.Y. Times, June 18, 1971, at 78, col. 6; id., June 20, 1971, $\$ 4$, at 3, col. 1; Wall St. J., June 22, 1971, at 5, col. 2; id., June 23, 1971, at 38, col. 1 ; id., June 24. 1971. at 6 . col. 3; N.Y. Times, June 24, 1971, at 79, col. 3; Wall St. J., June 25, 1971, at 10, col. 1, and at 18, col. 4; N.Y. Times, June 27, 1971, $\$ 5$, at 26, col. 1; Wall St. J.. June 28 , 1971 , at 6, col. 2; N.Y. Times, June 30, 1971, at 82, col. 1; id., July 1, 1971, at 84, col. 4; id., July 3,1971 , at 50 , col. 1 ; id., July $4,1971, \$ 4$, at 19 , col. 6 ; id., July 11,1971 , $\$ 10$, at 35 , col. 1; id., July 18, 1971 , $\$ 10$, at 31 , col. 1 ; id., Aug. $1,1971, \$ 1$, at 51 , col. 1 ; id., Aug. 5, 1971, at 66 , col. 1 ; id., Aug. 7,1971 , at 48 , col. 5 ; id., Aug. 8, 1971, $\$ 10$, at 4 , col. 6; id., Aug. 12, 1971, at 66, col. 5; id., Aug. 13, 1971, at 1, col. 1; id., Aug. 14, 1971, at 50, col. 6; id., Aug. 15, 1971, $\$ 4$, at 5 , col. 1; id., Scpt. 16, 1971, at 1, col. 2; id., Sept. 22. 1971 , at 14 , col. 1 ; id., Sept. 23, 1971, at 1, col. 7; Wall St. J., Sept. 27, 1971, at 4, col. 2; N.Y. Times, Sept. 28, 1971 , at 78, col. 4; id., Oct. 17, 1971, \$10, at 27, col. 1; id., Nov. 20, 1971 , at 62 , col. 4 ; Wall St. J., Nov. 22,1971 , at 9 , col. 3 .

Summaries of the 1971 IATA crisis may be found in Hoffman, The Great Air Fare War and What It Means to You, N.Y. Times, Dec. 5, 1971, $\$ 10$, at 1, col. I, and in S. REP. No. 92-593, 92d Cong., 2d Sess. $12-16$ (1972), reprinted in 118 CoxG. REc. 52460.61 (daily ed. Feb. 24, 1972).

4. The attack began with the dissent to the Civil Acronautics Board's decision to ap. prove American air carriers' participation in LAT.A. LATA Traffic Conference Resolution, 6 C.A.B. 639, 646 (1946) (Member Lec, dissenting). See note 68 infra. The Aviation Consumer Action Project, affiliated with Ralph Nader, recently filed a suit secking to overturn this original acceptance of IATA by the CABB. Civil Action No. 2188-7i (D.D.C., filed Nov. 1, 1971). See N.Y. Times, Nov. 2, 1971, at 41, col. 1.

The "cartel" label as applied to IATA was discussed at length in Fearings on Afonopoly Problems in Regulated Industries before the Antitrust Subcomm. of the House Comm. on the Judiciary, 84th Cong., 2d Sess., ser. 22, pt. 1, at 1048-54 (1957). Cf. note 119 infra. 
ing air fares as a relatively successful means of resolving disputes among sovereign states in an orderly, non-coercive manner. By affording an informal forum for the settlement of conflicts over economic practices in an industry of vital importance to most states, IATA provides a mechanism for the compromise of national interests without the appearance of compromising national integrity. While the existing system operates in some respects disadvantageously to the United States, significant improvements can be made within the IATA context. Ameliorative measures affecting the American role within IATA would avoid the risks inherent in unilateral efforts to "deregulate" international air transport: interruptions of air service, politicization of the regulatory process through the assumption of the price-fixing function by governments as an officially diplomatic task, and consequent burdens on trade and communications.

To be sure, IATA agreements serve to insulate IATA members from price competition and many forms of service competition. But this insulation from competition is not in itself at odds with American public policy, for domestic American airlines are similarly protected. The protection of domestic carriers has been linked, however, with protection of the public interest by a responsible governmental agency. Through the comprehensive powers vested in the Civil Aeronautics Board (CAB), commercial aviation within the United States has been subjected to strict economic regulation. ${ }^{5}$ Congress has not chosen, however, to exercise its right under international law to give the $C A B$ similarly comprehensive powers to protect and promote the public interest by setting fares in international commercial aviation. Furthermore, of all major aeronautical states which participate in IATA's ratemaking process, only the United States delegates the role of spokes. man for the public interest to privately owned airlines. ${ }^{6}$

American participation in IATA has thus lacked the imprimatur of governmental authority necessary for the American public interest in economical air fares to be given fair consideration. Growing consciousness of American impotence in the international fare-setting

5. The Givil Aeronautics Act of 1938, ch. 601, 52 Stat. 973 (repealed 1958), created the Civil Acronautics Authority (CAA). The CAA became the CAB pursuant to Reorganiza. tion Plan No. IV, 54 Stat. 1234, transmitted to Congress on April 11, 1940, by President Roosevelt under the authority of the Reorganization Act of 1939, ch. 36, 53 Stat. 561. No change in the CAA/CAB's powers of cconomic regulation was involved. Reorganization Plan No. IV, § 7(b), 54 Stat. 1235. The Federal Aviation Act of 1958, 49 U.S.C. \$\& 1301 If. (1970), re-enacted the economic regulatory provisions of the 1938 Act "virtually without substantive change," in the words of a $\mathrm{CAB}$ staff attorney. Lindsey, The Le'gislative $D_{c}$. velopment of Civil Aviation 1938-1958, 28 J. AIR L. \& CoM. 18, 33 (1962).

6. See note 111 infra. 
process has prompted Congress to pass the 1972 amendment ${ }^{7}$ to the Federal Aviation Act, ${ }^{8}$ enabling the $\mathrm{CAB}$ to disapprove fares of international airlines. While this remedial legislation should enhance American influence within IATA, it is disturbing that Congress discarded a preferable alternative-empowering the $\mathrm{CAB}$ itself to prescribe international air fares. ${ }^{9}$

This Note will examine the legislation which was before the Congress and analyze the role the $C A B$ can and should play in establishing international air fares. After placing IATA in its historical context, the politics of IATA will be explicated and it will be shown that the United States has been placed at a disadvantage in IATA negotiations because of deficiencies in the powers of the CAB. Following a discussion of the need for continued regulation of international air fares, Congress' choice between alternative means of enhancing American influence within the regulatory process will be criticized and the optimal role of the $\mathrm{CAB}$ delineated.

\section{Evolution of an International Legal Process for the Regulation of Air Fares}

\section{A. Origins in Europe and the United States}

The International Air Transport Association is a reincarnation of the International Air Traffic Association, which was formed in 1919 and terminated by the Second World War. ${ }^{10}$ An institution such as the old IATA was essential to the development of scheduled air service in Europe. The small size of the European states meant that any flight of sufficient length to provide significant economies of time over surface transportation was almost certain to cross national boundaries. As a consequence, no European country could develop its civil aviation industry primarily within a domestic market.11 Commercial aviation was to be almost synonymous with international aviation. More-

7. Act of March 22, 1972, Pub. L. No. 92-259, 86 Stat. 95,1972 U.S. CodE CoNG. \& AD. News 806; see pp. 1135-36, 1146.49 infra.

8. 49 U.S.C. $\$ \S 1301$ ff. (1970).

9. S.2423, $92 d$ Cong., Ist Sess. (Aug. 4, 1971), referred to as the CAB draft of S.2423, or "paragraph (e) powers." See p. 1146 ff. infra.

10. S. Cohen, IATA: The First Three Decades 14, 78 (1949).

11. This was the single most important difference between Europe and the United States in their respective development of airlines. The continental span of the United States could encompass an efficient air transport system within a single sovereign jurisdiction. Cf. notes 20-22 infra. Compare H. Sarrh, Alrways (1942), wilh R. Hicilai, Iratais's IMPERIAL AIr Routes 1918 to 1939 (1960) and S. WheAtcroft, THe Ecosoaics of Eunopean AIr Transport (1956). 
over, the trans-national nature of the European air commerce market meant that no one state had plenary jurisdiction to regulate the eco. nomics of air transport. Yet the struggle to recover from the destruction and dislocation of resources caused by World War I bred sharp economic rivalries among the European governments. ${ }^{12}$ This friction inhibited recognition of a common interest in commercial aviation and prevented cooperative, inter-governmental regulation of European air transport. The carriers themselves thus assumed responsibility for the concerted action necessary to promote commercial aviation through the establishment of uniform conditions of carriage and the rationalization of routes and schedules.

Although unable to affirm a common interest in the development of commercial aviation, European governments were quick to employ civil air transport to advance their individual national interests. Within a few years of the Armistice of 1918, extensive government ownership and subsidization of the major national airlines had become the norm in Europe. The colonial empires of the victorious Grand Alliance powers had emerged from the First World War intact. Aviation promised to provide speedy communication between the imperialist countries and their colonies. As a means of gaining and maintaining influence, the civil air power of any one country threatened the imperial security of the others; hence, the European governments viewed commercial aviation more as an instrument of state than a profit-making business, and plowed immense amounts of capital into its development. ${ }^{13}$ Direct subsidies to the national carriers flying intra-European routes became routine. ${ }^{14}$ By the mid-twenties, the imperial routes began to inch across the map, first over the Mediterranean, then on to Asia and Africa. ${ }^{15}$.

For those without empires, there was South America. Private German capital began setting up airlines within South America as early as 1920. Within six years, the German government had assumed control of most of these lines, and Germany pushed forward vigorously to

12. See generally R. Sontag, European Diplomatic History 1871-1932, at 305.22 (1933); E. Carr, The Twenty Years' Crisis 1919-1939, at 54-60 (1964 ed.).

13. O. Lissitzyn, supra note 1 , at 137-99.

14. See, e.g., R. HighaM, supra note 11, at 39-75; L. Tombs, supra note 1, at 31.33 . Once subsidization became the norm, it also became a necessity for survival. No unsub. sidized carrier could weather the predatory tactics of the subsidized lines. See R. Hicilas, supra, at 44-45. For a table listing the amounts of subsidy paid to civil aviation by principal aeronautical countries during the years 1933-1936 sce Appendix III, Battisit Air Ministri, 1936 Report on the Progress of Civil Aviation 136.42 (1937).

15. R. Davies, A History of the World's Airlines 170.86 (1964); R. Highiam, stupra note 11 passim; $\int$. Stroud, AnNals of British and Commonwenltil AlR Transtokt 23.175 (1962). 
establish a network of German-financed airlines serving the intracontinental South American air transportation market. ${ }^{10}$

Pan American was the only American international airline of the inter-war period, ${ }^{17}$ and its development paralleled the European model in many respects. The company was first formed in 1927, as an American rival to the German aviation interests in South America, which seemed to threaten the Canal Zone. ${ }^{18}$ Pan Am's subsequent Clipper service across the Pacific received strong support from the Navy. ${ }^{10}$ Most important of all, PAA received a subsidy from the government which not only went uninterrupted by the scandal which terminated domestic airline subsidies in $1934,{ }^{20}$ but was also far in excess of that received by any domestic American air carrier. ${ }^{12}$

16. W. Burden, The Struggle for Airisays in Latis AMEMact 11-13, 38-46 (IH3).

17. Pan American actually consisted, for tax purposes, of three separate operating corporations controlled by a single holding company. All of these operations, plus lan American-Grace Airways (of which $\mathrm{Pan} A \mathrm{~m}$ and the Grace Steamship Company each owned one half) are referred to in this Note as "Pan .Imerican," "Pan Am," or "P.1.1." For Pan Am's corporate structure during this period, sec G. Goodsas, Govensitest lozICY TOWARd COMMERCIAL Aviation 81 (1944).

18. H. SMith, Airways Abroad 10.14 (1950); M. JoserhoN, EMrire of tile Ain 43, 51 (1944).

19. H. SMITH, supra note 18 , at 34 .

20. The Army carried all domestic air mail in the United States until 1926. The Air Mail Act of 1925, ch. 128, 43 Stat. 805, allowed private airlines to bid for air mail contracts for the first time. Five years of confusion followed as various schemes for compensating air mail carriers were tried out, at a time when air mail was the only signifi. cant source of revenue for the domestic airlines. Finally, l'resident Hoover's Postmaster General Walter F. Brown acquired in the Watres Act of 1930 near dictatorial powers to control air mail contracts. Act of April 29, 1930, ch. 229, 46 Stat. 259. Brown quickly set about hammering out an efficient route system. Through forced mergers and the manipulation of contract requirements so as to cxclude bids by small operators, the "Big Four" trunk carriers extant today, United, Eastern. TWA, and American, eninerged with most of the air mail contracts.

When an investigation chaired by Senator (later Justice) Hugo Black uncovered the full extent to which Postmaster General Brown had pushed his discretion, see Hearings before a Special Comm. on Investigation of Air Mail and Occan Mail Contracts, US. Sen., 73d Cong., 2d Sess. (1933), New Dealers were quick to attack Brown's actions as typical of the high-handedness with which the Republicans had sold the little man down the economic river to Depression. Amid charges of collusion and a "spoils conference," all domestic air mail contracts were cancelled by Roosevelt's Postmaster Gencral, James $A$. Farley. By executive order later backed up by statute, the .Irmy reasstumed its carlier responsibility for the carriage of air mail. Exec. Order No. 6591, Feb. 9. 1931; Act of March 27, 1934, ch. 100, 48 Stat. 408. See generally H. SMru, supra note 11 fassim; S. Richmond, Regulation and Competion in AIR Transportation 4-6 (1961); C. RIISE, The Civil Aeronautics Act AnNotated 20.23 (1939).

21. Until passage of the Civil Aeronautics Act, there was no explicit segregation of federal subsidy payments from federal air mail pajments generally. The extent to which federal mail contracts were implicitly subsidizing the airlines was usually calculated on the basis of the difference between govermment receipts and government cxpenditures on air mail. See J. Frederick, Commerciat. Air Trassiortation 240 (1942). On this basis, Pan American and its jointly-held subsidiary, Pan Americall.Grace. see note 17 supra, received $\$ 47,202,000$ in subsidy for the eleven fiscal years July 1, 1929.June 30, 1910. The total subsidy received by all American domestic airlines for the same period was $\$ 59,852,000$. During this time, the domestic airlines flew some eight times the passengermiles that Pan Am did. Although the average mail pajment per mile llown by Ian $\mathrm{Am}$ decreased forty-three per cent between 1930 and 1940 , it was still in 1940 three times the amount paid per mile to domestic carriers. W. BurDEs, supra note 16, at 116-17. 
The disruptions of domestic aviation in 1934 touched off four years of congressional debate over the proper role of the government in the regulation of civil aviation. ${ }^{22}$ The culmination of this debate was the Civil Aeronautics Act of 1938,23 which subjected the domestic air transport industry to a comprehensive program of economic regulation. The cornerstone of this regulation was plenary governmental control over rates charged for air transportation.

In 1938, the limited range of commercial aircraft made long-distance international service dependent on a network of refuelling stations. Transatlantic service had not yet been inaugurated. No foreign airline provided regular service to the United States. ${ }^{24}$ The severe competition of foreign airlines which Pan American encountered in South America was confined within that intra-continental market, beyond the jurisdiction of the United States government. ${ }^{25}$

For these reasons, the Civil Aeronautics Act of 1938 focussed almost exclusively on the manifold problems of the domestic air carriers. Provision was made for licensing Pan American, and for controlling entry into the market (and American airspace) of those international air carriers, both foreign and American, which might seek operating

22. The Army's resumption of responsibility for the air mail proved disastrous, and was abandoned two months later after the deaths of twelve pilots and a four.fold increase in the cost per mile to the government for the movement of mail. H. SMirit, supra note 11 , at $251,255-57$.

This fiasco allowed Roosevelt's opponents to regain the political initiative. Brown's policies had obviously produced a measure of national benefit as well as private profits. Both sides were mollified by the Air Mail Act of 1934, ch. 466, 48 Stat. 933, which re pealed existing legislation and awarded regulatory powers over air mail carriers to threc agencies. The Post Office was to award contracts and determine routes and schedules; the Interstate Commerce Commission was to adjust the contracted rates of compensation when necessary; and the Department of Commerce was to provide technical regulation.

It soon became apparent that air mail was no longer an effective means for controlling the development of commercial aviation. Passenger and freight revenuc provided in 1938 nearly twice as much income for domestic air mail carriers as did mail payments thent. selves. C. RHYNe, supra note 20, at 2. The route system created by Postmaster Gencral Brown was endangered by competitors which siphoned off passenger reventic from mail carriers, contrary to the favored policy of "internal" subsidization whereby the passenger revenue on heavily-travelled routes was expected to reduce the cost of mail service on lightly-travelled routes. See, e.g., S. RichmoND, supra note 20, at 73-74, 154-58. An amend. ment to the Air Mail Act, Act of Aug. 14, 1935, ch. 530, 49 Stat, 614, sought to limit competition for passenger revenue among mail carriers, but failed to reach airlines without mail contracts. The severity of the competition led the major airlines themselves to be active lobbyists for the comprehensive regulation of domestic air transportatiou established by the Civil Aeronautics Act of 1938. See generally C. RHYNe, supra note 20, at 6-7, 41-65, 189-220; F. Thayer, Air Transport Policy and Natronal Security 16.18 (1965). See also Westwood \&. Bennett, A Footnote to the Legislative History of thc Civil Aeronautics Act of 1938 and Afterward, 42 Notre DAME LAWYER 309 (1967).

23. Ch. 601,52 Stat. 973 (repealed 1958).

24. See Hearings on H.R. 9738 (To Create a Civil Aeronautics Authority) before the House Comm. on Interstate and Foreign Commerce, 75th Cong., 3d Sess. 40.41, 976 (1998),

25. W. BURDEN, supra note 16, at 16-17, 60-61. Hearings on S. 3659 (Civil Aviation and Air Transport) before a Subcomm. of the Senale Comm. on Interstate Commerce, 75th Cong., 3d Sess. 11 (1938). 
rights in the future. ${ }^{20}$ On the crucial question of government control over the rates of international carriers, however, action was deferred pending further study. ${ }^{2 \pi}$ For the moment, international airlines were left to their own economic devices. ${ }^{28}$

26. Entry into the market was controlled through $\$ \$ 401$ and 402,52 stat. $987-92$ (superseded by 49 U.S.C. $\$ \$ 1371$ and 1372 (1970)), see p. 1134 in/ra. Yan American's continued operating rights were assured by a "grandfather clause," \$ 401(c), 52 Stat. 988.

27. $\$ 404(c), 52$ Stat. 993. See Hearings on S. 3760 (Civil Aeronaulies Authority) before a Subcomm. of the Senate Comm. on Commerce, 75th Cong., 3d Sess. 2.3 (1938).

28. One commentator has persuasively argued that the uneasy sjmbiosis of the Thirtics between Pan American and the United States government provided the pattern for American policy on international aviation after the Second W'orld War. According to F. ThaYer, supra note 22 , at $33-37$, the scenario was as follows:

In the mid-1920's, American military officials became alarmed at the mounting German influence in South America, and in particular at the operations of the German-controlled Colombian airline, SCADTA, which operated in proximity to the Panama Camal. Consultations with the Post Office revealed that in liet of any Imerican bids, a contract for Latin American mail might go to SCADTA. The officers managed to interest some entrepreneurs in forming an airline for Latin American operations, and the Post Office obligingly denied the Colombian airline's request for a contract. Pan . Imerican was the first of several airlines to be organized for the exploitation of the South Ameriean market. By obtaining exclusive landing rights from Cuba, I'an Am obtained a pre-cminent position, and when the Air Mail Act was amended in 1930 to give the l'ostmaster General near-plenary power over air mail routes, see note 20 supra, 1.1.1 was cstablished as the only American overseas carrier. With occasional aid from the State Department, l'an Am built up an extensive system of traffic rights throughout Latin America. This reinforced its monopoly position as the only American international airline, so that it could submit bids for air-mail contracts at the highest legal rate and fear no competition. P.1.1's cxclu. sive rights in Latin America and the Rooserelt Administration's concern for its Good Neighbor Policy insulated Pan Am from the repercussions of the air mail seandal of 1934, when all domestic airline contracts were cancelled as collusive. Its position sccure in South America, Pan Am turned to the Pacific region for the next extension of its route network, this time receiving substantial support from the Nasy.

Under the "grandfather clause" of the Civil Aeronautics . Ict, Pan .Im as an cxisting air carrier was granted the right to a certificate of public convenience and necesity upon a pro forma showing of its prior operations. The Roosevelt Administmtion did not like Pan Am's monopoly status in American overseas aviation, but the grand. father clause and Pan Am's stranglehold on foreign landing rights shiclded the airline from any immediate steps to introduce competition into the iniernational air transport field. While Administration spokesmen were attacking Pan Am publicly, the adient of the Second World War in Europe forced secret government funding of Pan Im's Latin American operations, through which some fifty airports were built or improved, for later use as the principal network for channeling aircraft and supplies to Great Britain sia Africa and Portugal. The Government also financed Pan Am's acquisition of German interests in various South American airlines.

In the midst of this covert support of PAA, an American slipping company organized a competing transatlantic carrier, American Export Airlines (A.IEX). Pan Am had obtained a certificate for Atlantic service to England in 1938, along both a northerly; Canadian route and a southern route via Lisbon. Soon after service was inaugurated in 1939, the war sealed off Britain, but the Lisbon route continued to offer access to Continental Europe. Portugal was ready to grant traffic rights to a second airline, and AMEX's application for a certificate was seized upon by the $C_{A B}$ and the Administration as an initial step in breaking the Pan American monopoly.

Given the existing traffic to Europe, however, a second airline was not commercially justified. Increased air-mail payments would therefore be essential to stpport both Pan Am and a competitor on the transatiantic route. Pan Am succecded in marshalling its congressional allies and defeating the requisite appropriations, halting AMEX's planned operations and handing Roosevelt a bitter political defeat. As a result, the Administration was to keep one eye open throughout the war for the opportunity to end Pan American's monopoly when peace returned. 


\section{B. The Chicago Conference}

The Second World War brought to sudden maturity the long-haul, land-based transport aircraft. The flying boats of prewar international aviation were relegated to patrol duty, and were replaced as transports by four-engined airplanes designed for the long distance flights necessary to supply Allied forces and bomb Axis countries. ${ }^{20}$ With its newly developed range and power, aviation was clearly destined to be a major force in the postwar world, from a commercial as well as a military perspective. ${ }^{30}$ To establish the legal underpinnings for a global air transport system, the United States convened an International Civil Aviation Conference in Chicago on November 1, 1944..$^{31}$

The United States advanced a convention creating virtually total "freedom of the air" through a multilateral exchange of the so-called "Five Freedoms." 32 The scheduled carriers of parties to the treaty would have nearly unrestricted rights of commercial operation to and through all other parties. Economic decisions as to fares, frequencies, and routes would be left to the discretion of airline managements, sub-

29. F. ThAYER, supra note 22, at 49-50; John A. Miller, Air Diplomacy: The Chi. cago Civil Aviation Conference of 1944 in Anglo-American Wartime Relations and lostwar Planning, at 51, 59-62, March, 1971 (unpublished Ph.D. thesis in Yale University Library).

30. Id. at 78 .

31. Id. at 177. Fifty-two countries sent voting delegates to the Conference. In addition, two nations were represented by non-yoting observers. 1 U.S. DEI'T OF STA'TE, PHOcEED INGS OF THE INTERNATIONAL Civil Aviation CONFERENCE 13, 119 (1948) [hereinafter cited ats Chicago Proceedings]. The Soviet Union was invited, but recalled its delegation as it was en route to Chicago, allegedly because of the participation of threc ncutral countries, Spain, Portugal, and Switzerland, whom the Soviets accused of having had Axis synipa thies. R. Thornton, International. Airlines and Politics 22 (1970); W. O'Connok, Eco. NOMic Regulution OF THE WORLD's Airlines 29 (1971).

32. The International Air Transport Agreement setting forth the Five frecdoms atp. pears in Chicago Proceedings, supra note 31, at 179. The considerations leading to the American position are explored in Miller, supra note 29 , at 86.114 . For a look at somc of the ambiguities of the International Air Transport Agreement see W. O'CoNNok, supra note 31, at 42-45. The International Air Transport Agreement, which was in effect bricfly between the United States and a few other states, cf. note $42, \mathrm{infra}$, defined as follows tho "Five Freedoms," which have since become a basic part of air transport jargon:

Each contracting State grants to the other contracting States the following frecloms

of the air in respect of scheduled international air services:

(1) [Transit] The privilege to fly across its territory without landing;

(2) [Technical stop] The privilege to land for non-traffic purposes;

(3) [Out-bound traffic stop] The privilege to put down passengers, mail and cargo

taken on in the territory of the State whose nationality the aircraft posicsses:

(4) [In-bound traffic stop] The privilege to take on passengers, mail and cargo destined for the territory of the State whose nationality the aircraft possesses;

(5) [External traffic stop] The privilege to take on passengers, mail and cargo destined for the territory of any other contracting State and the privilege to put down passengers, mail and cargo coming from any such territory.

With respect to the privileges specified under paragraphs (3), (4) and (5) of this section, the undertaking of each contracting State relates only to through services on a route constituting a reasonably direct line out from and back to the homcland of the State whose nationality the aircraft possesses.

International Air Transport Agreement, Dec. 7, 1944, art. I. $\$ 1,59$ Stat. 170 (19.15), E.A.S. No. 448 . 
ject to whatever conditions were placed upon their operating rights by their own governments. Since the $C A B$ had no power to control international fares, American international airlines would thus be subject to no economic regulation whatsoever. ${ }^{33}$

The United States saw this delegation of economic decisions to the airlines as the international embodiment of the American free enterprise system. Ease of entry and competitive pricing would allow the market efficiently to match supply and demand. Other nations were not blind to the fact that this competitive model reflected more the myth than the reality of the American air transport industry. True, the tremendous growth of American domestic aviation during the thirties had been financed by private capital, but air mail contracts had provided concealed operating subsidies. ${ }^{3 t}$ The comprehensive regulatory scheme of 1938 had not only controlled entry into the domestic airline business but had provided rate regulation as well, to the great relief of existing airlines, which had become locked into socalled "uneconomic" rate wars. ${ }^{35}$

More than this gulf between the theory and practice of American "free enterprise" aviation policy served to make the lofty internationalism of the United States' call for "freedom of the air" ring hollow. The United States possessed in 1944 a competitive advantage in commercial aviation of overwhelming magnitude. The United States had not only a huge surplus of transport equipment poised to enter the international air transport market, ${ }^{36}$ but also thousands of experienced pilots already familiar with the routes to be flown. ${ }^{37}$ For the Europeans, with devastated economies and obsolete equipment, a com-

33. Aside from $\mathrm{CAB}$ certification to fly a particular routc, see note 26 supra.

34. Cf. note 21 supra. The federal government also expended through 1940 some $\$ 126,468,000$ on the maintenance and construction of domestic airway facilities. W. BurDEN, supra note 16 , at 116 .

35. Cf. note 22 supra.

36. The aircraft and airline industries of most of Continental Europe had, of course, fallen into Nazi hands. Britain, by agreement with the United States, had concentrated on fighter production. The United States had in turn channelled its aircraft industry primarily into the production of bombers and transports. Afiller, supra note 29, at 64, 76; Thorston, supra note 3I, at 23. DAvies, supra note 15, at 239, admits the disparate emphases of A'yerican and British wartime aircraft production, but denies the cxistence of any agreement to that effect. But of. A. JACkson, I Brrrisil Civil AirCrafr 1919-1959, at 121 (1959); H. SMrrH, supra note 18, at 70 .

37. Through a complex military-civilian airlift system (motivated in part by the Roosevelt Administration's continuing desire to open the international mariet to American competitors of Pan Am ( $c f$. note 28, supra)), American domestic airlines had joined Pan American in setting up and flying global routes under military contracts to supply Allied forces. F. THAYER, supra note 22, at 49-55; H. SMrri, supra note 18, at 63.91; L. Zacharoff, The Wordo's Wings 7-8 (1946). Pan American saw the threat to its position, and bitterly opposed Roosevelt's "Freedom of the Air" policy at Chicago. See Cone, International Air Transportation, in VITAL Pronless of AIs Cossusece 17 (L. Zacharoff ed. 1946). 
petitive market would have meant extinction of their aviation capabilities.

As the prewar subsidy battles of the imperial airlines had shown, anti-competitive devices were to the Europeans an accepted method for protecting national interests. The European position, as articulated by the British, was accordingly to demand an international regulatory authority with powers to control rates, routes, and schedules as a prerequisite to the surrender of sovereign control over national airspace. ${ }^{\text {s }}$ Such an international agency would uphold the economic and security interests of each nation by apportioning the available traffic among national carriers so as to ensure the coordinated development of each state's aviation capability..$^{30}$

There was nearly unanimous accord at Chicago on the propriety of a reciprocal grant of the rights (1) to fly over a country without stopping and (2) to stop for fuel or servicing without picking up or discharging passengers and freight. These so-called First and Second Freedom rights ${ }^{40}$ were exchanged through signature of the International Air Services Transit Agreement. ${ }^{41}$ Due to the regulatory demands of the Europeans, the Conference was unable to reach general agreement on the exchange of so-called Third, Fourth, and Fifth Freedom rights. ${ }^{42}$ These traffic rights permit a given country to provide air service from that country to a second country and from the second country back to the first country (Third and Fourth Frecdoms), and for the first country's airline to provide air service from

38. Speech of Lord Swinton, chairman of the United Kingdom delegation, Chicago Proceedings, supra note 31, at 63-67. The Canadians drew an explicit parallel to the CAB's domestic jurisdiction. Specch of C.D. Howe, head of the Canadian delegation, $i d$. at 67-74. See generally W. O'CoNNor, supra note 31, at 20-29; Miller, supra note 29, att $115-45$.

39. The British and their allies at Chicago were not without bargaining power. The United States' technological advantages were offset by British and European gco.political advantages. By a concerted denial of landing rights to American airlines, the Europerans could lock the United States out of the transatlantic air transport market-the United States would have no "Third and Fourth Freedom" traffic to Europe. The Europeans could meanwhile serve the transatlantic market through Canada. Moreover, the British together with the Commonwealth countries could provide round-the-world service on at "All-Red" route, red being the color traditionally used in atlases to designate territory under British dominion. Should the Commonwealth countries join Britain and Europe in an American boycott, no rival American global air service would be possible becaltsc the need for fuel as well as "Fifth Freedom" traffic made long-haul air routes dependent on a good number of intermediate landing spots. See R. THorNron, supra note 31, at 28-29.

40. Cf. note 32 supra.

41. Dec. 7, 1944, 59 Stat. 1693 (1945), E.A.S. No. 487.

42. Cf. note 32 supra. The International Air Transport Agreement was signed by only a few minor countries besides the United States. Following the Bermuda Conference, sec pp. 1114-17 infra, and the Senate's ratification of the Convention on International Civil Aviation, see note 43 infra, the United States denounced the International Air Transport Agreement on July 25, 1946, effective July 26, 1947. Department of State Press Relcase No. 510 (July 25, 1946), 3 Av. L. REP. If 26,300, at 22,728 (June 9, 1958). 
the second country to third countries (Fifth Freedom). Recognizing "that it is desirable to promote early development in this field [of international aviation] during a transitional period, in order to obtain practical experience for giving effect to more permanent arrangements at a later date," the Final Act of the Chicago Conference sought to outflank the impasse over economic regulation by providing a standard form for "provisional" agreements exchanging Third, Fourth, and Fifth Freedom rights on a bilateral basis. ${ }^{43}$

\section{The Resurrection of IATA}

The final meeting of the prewar IATA had, in 1938, elected Pan American Airways as its first North American member, and in recognition of the coming era of transatlantic air service had scheduled its next meeting for New York in September, 1939.4 The outbreak of war ended IATA operations, but many of the officials of its Continental members congregated in London and attached themselves to the various governments in exile established there. ${ }^{45}$ Many of these businessmen-cum-bureaucrats attended the Chicago Conference as delegates and advisors, and when the economic stalemate among governments became apparent, they arranged a meeting of airline operators in Chicago immediately after the formal Conference adjourned. ${ }^{40}$ Several of the American domestic airlines, having expanded into the international field through their wartime airlift operations, were among the thirty-four airlines represented at this convocation.

A conference in Havana in April, 1945, approved Articles of Association which extended membership in the reconstituted International Air Transport Association to any scheduled international carrier flying the flag of a member state of the newly formed International Civil

43. Chicago Proceedings, supra note 31, at 127-29. Except on the issue of cconomic controls, the Chicago Conference was a splendid stccess. A Convention on International Civil Aviation, Dec. 7, 1944, 61 Stat. 1180 (1947), T.I.A.S. No. 1591 (effective April 4, 1917), set up technical standards for aerial navigation, and created the International Civil Asiation Organization (ICAO), a multi-level body for the promotion of international aviation. A Provisional International Civil Aviation Organization (PICAO) was established by executive agreement to perform the duties of the ICAO until such time as the Convention on International Civil Aviation was ratified as a treaty. Interim Agrcement on Intermational Civil Aviation, Dec. 7, 1944, 59 Stat. 1516 (1945), E.A.S. No. 487.

The ICAO is empowered to "study any matters affecting the organization and operation of international air transport, including the international ownership and operation of international air services on truck routes ...." Convention on International Civil Aviation, art. 55 (d), 61 Stat. 1197 (1947), T.I.A.S. No. 1591, at 22. The IC1O has nevertheless eschewed participation in the international legal process for regulating air fares. See K. PILlai, The AIR NeT 122-36 (1969). See generally T. Buercenthal, Laiv-Makisic in the INTERnational Civil Aviation Organization (1969).

44. S. CoHeN, supra note 10 , at 77 .

45. Id. at 79.80 .

46. Id. at 80 . 
Aviation Organization (ICAO). ${ }^{47}$ These Articles established as the aim of IATA the development of international commercial aviation in cooperation with the ICAO. The unwritten assumption of the carricrs involved was that IATA would resume its prewar function of providing a forum for "informal" price-fixing and divisions of the market. ${ }^{48}$ This intention was made explicit when IATA voted unanimously in October 1945 to set up regional "Traffic Conferences." 40 These conferences consider and act upon "all international air traffic matters ... particularly the following:- . . fares, rates and charges for passengers and cargo; [and] schedules . . . ."50 Actions are dependent upon the unanimous agreement of all carriers operating in a given region. ${ }^{\text {th }}$

It was not immediately apparent whether such unanimity would be forthcoming from the airlines any more than from the governments themselves. In October, 1945, Pan American announced plans to drop its North Atlantic fares by nearly thirty per cent. ${ }^{52}$ The ensuing uproar in Great Britain and France made it clear that these governments would insist on some form of rate control in international aviation. ${ }^{63}$ In December, 1945, when IATA was incorporated in Montreal-the site of ICAO-it was still unclear what role IATA would play in providing this control. ${ }^{54}$

\section{The Bermuda Bilateral}

The United States and Great Britain met in Bermuda in January 1946 to work out a bilateral air services agreement. ${ }^{55}$ This was to be the first significant "provisional"5s agreement pending multilateral

47. Id. at 102; cf. note 43 supra.

48. S. CoHen, supra note 10 , at 64 .

49. Id. at 82; IATA Traffic Conference Resolution, 6 CAB 639, 640 (1946). The Conferences were originally nine in number, but were reduced to the present number of threc within two years. S. CoHEN, supra note 10, at 87; IATA Traffic Conference Resolution, 9 CAB 221 n.4 (1948).

50. Provisions for the Regulation and Conduct of the IATA Traffic Conferences, art. IV, \$ 1(ii), (iii) International AIr Transport Association, Rules \& Regulations 55 (8th pub. 1966), reprinted in A. Chayes. T. EhrLich \& A. LoWEnfeld, International Li'Gal Process, Documents SUPPLEMENT 274-77 (1968).

51. Id. at art. VII, $\$ 1$. For descriptions of the mechanics of IAT $A$ tariff negotiations see Gazdik, Rate-Making and the IATA Traffic Conferences, 16 J. AIR L. \& C. 298 (1949); Koffler, IAT A: Its Legal Structure-a Critical Review, 32 J. Aik L. \& C. 222, 224.27, 230.32 (1966). See also the book and articles by S. Ralph Cohen, former Public Relations Officer of IATA, cited in note 117 infra.

52. The proposed reduction was from $\$ 375$ (one way) to $\$ 275$. H. SMrTil, supra notc 18, at $251-52$

53. Id.

54. S. CoHen, supra note 10 , at 82 .

55. Air Services Agreement with the United Kingdom of Great Britain and Northern Ireland, Feb. 11, 1946, 60 Stat. 1499 (1946), T.I.A.S. No. 1507 [hereinafter cited as Bermuda bilateral].

56. Cf. p. 1113 supra. 
accord on the exchange of traffic rights, ${ }^{57}$ and was destined to serve as a model for most subsequent bilateral agreements to which the United States has been a party.58 In return for Britain's retraction of its demand at Chicago for controls on the number of flights each party could offer over a particular route, the United States agreed to economic regulation under the auspices of IATA. 00

Under the Bermuda bilateral, the IATA "rate conference machinery," consisting of negotiation among the carriers, was given primary responsibility for setting fares, subject to virtually unrestricted rights of disapproval by the aeronautical authorities of either government. ${ }^{60}$ A detailed procedure was set up to deal with "open-rate"

57. Proposals for multilateral air service agreements continued to abound, and pro. voked much discussion, until interest waned after 1953. Sec W. O'CoNsor, supra note 31 , at 49.85 .

58. Bilateral air transport agreements to which the United States is a party are collected at 3 Av. L. REP. 926,305 (Aug. 18, 1971). About threc-quarters of ulese, including those with nearly every major country except the Soviet Union, are "Bermuda-type" agreements. See Hearings on H.R. 1716, H.R. 6100, and S. 1510 (Rates and Practices in Foreign Air Transportation-1964) before the House Comm. on Interstate and Foreign Commerce, 88th Cong., 2d Sess. 30 (1965). The Bermuda bilateral and the others which followed it until 1948 were composed of the form language sct forth for bilaterals by the Final Act of the Chicago Conference, see p. 1113 supra, plus an "Annex" which contained the provisions concerning routes and rate controls which had been the substantive subject. matter of the bilateral negotiations. Thus it was the Innex to the Bermuda bilateral, $c f$. note 60 infra, which became the model for subsequent bilaterals. By 1948 the Bermuda Annex had become so much the norm, insofar as it solved the problem of rate control through delegation of rate-making competence to IATA, that the provisions of the Annex concerning IATA were incorporated by the United States into a new "form" for bilateral air service agreements which the United States has used since 1948. "This new "form," sometimes referred to as the "Bermuda form," replaced the provisional "Chicago form" recommended by the Chicago Conference. Under the "Bernuda form," the Annex or Schedule is reserved for provisions assigning routes or othervise dealing with matters negotiated de novo with each separate bilateral partner of the United States. Thus the crucial paragraphs (e) and (f) which appear in $\$$ II of the Annex to the Bermuda bilateral, see note 60 and p. 1116 infra, appear in Article 11 of the "Bermuda form" of bilateral used since 1948. The "Chicago" and "Bermuda" forms are reprinted at $3 \mathrm{Av}$. L. REr. (Y 26,306 and 26,307 (June 9,1958 ). The specific bilateral usually cited as cxemplifying the "Bermuda form" is the Air Transport Agreement with the Fed. Rep. of Germany, July 7, 1955, [1956] 1 U.S.T. 537, T.I.A.S. 3536 .

The fact that the Bermuda bilateral itself, supra note 55, is the "Chicago" form with an Annex added hardly eases the confusion surrounding bilateral nomenclature. This Note refers to both the "Chicago form" of bilateral with a Bermuda-type Annex, and the so-called "Bermuda form" of bilateral which has been used since 1948 as "Bermuda-type" bilateral aix service agreements. There is one significant "Chicago form" bilateral still effective which, because it was entered into before the Bermuda conference, is not of the "Bermuda-type." This is the bilateral with Iceland, of. notc 105 infra.

59. See Address by George P. Baker, chairman of the United Siates delegation to the Bermuda Conference, McGill University, April 18, 1947, reprinted in part in $1 \mathrm{~A}$. CurAres, T. Ehrlich \& A. Lowenfeld, International Legat. Process 498.99 (1968).

60. The form of the Bermuda bilateral is as follows: the fourteen articles of the bilateral are mainly procedural, and follow the form recommended for bilateral agreements by the Chicago Conference. See p. 1113 and note 58 supra. The most important provisions of the bilateral are contained in the Annex. Section $I$ of the Annex provides that the exchange of air traffic rights in the Annex is made "in full accord and compliance with the principles recited and agreed in the Final Act of the [Bermudn] Conference." See note 66 infra. Section III specifies the routes exchanged by the parties, subject to amendment under $\$ I V$. Section V specifically invokes the capacity principles of the Final Act. See note 66 infra. The critical question of rate regulation is dealt with in $\$$ II. 
situations, which might result either from IATA carriers failing to reach an agreement or governmental disapproval of an IATA tariff agreement. The United States undertook "to use its best efforts" to secure for the $\mathrm{CAB}$ powers under American municipal law to fix and suspend rates for international aviation comparable to those exercised by the Board over domestic aviation. ${ }^{61}$ Until such time as the legisla. tion was obtained, however, in the event that either government was dissatisfied with a proposed new rate, the objecting government could act under paragraph (f) to prevent that rate from going into effect. ${ }^{02}$ Under the alternative paragraph (e), ${ }^{63}$ which was to be effective once the $\mathrm{CAB}$ had been given the power to set international rates, a government dissatisfied with a rate proposed by the other government dur-

The only arguable restriction on the plenary power of either party to disapprove an IATA agreement is posed by the vague language of paragraph (h), see note 65 infra. Ac. cording to paragraph (f), the sanctions there allowed until paragraph (f) is supplanted by paragraph (e) are conditioned on nothing more than "one of the Contracting l'artics [being] dissatisfied with any new rate proposed."

61. Bermuda bilateral, supra note 55 , Annex, $\$$ II, paragraph (i).

62. Bermuda bilateral, supra note 55, Annex, $\$$ II, paragraph (f):

Prior to the time when such power may be conferred by law upon the acronautical - authorities of the United States, if one of the Contracting Parties is dissatisfied with any new rate proposed by the air carrier or carriers of either Contracting larty for services from the territory of one Contracting Party to a point or points in the territory of the other Contracting Party, it shall so notify the other prior to the expiration of the first fifteen of the thirty day period referred to in paragraph (c) above, and the Contracting Party shall endeavour to reach agreement on the appropri. ate rate. In the event that such agreement is reached each Contracting Party will use its best efforts to cause such agreed rate to be put into effect by its air carrier or carriers. It is recognised that if no such agreement can be reached prior to the expiration of such thirty days, the Contracting Party raising the objection to the rate may take such steps as it may consider necessary to prevent the inauguration or conl. tinuation of the service in question at the rate complained of.

63. Bermuda bilateral, supra note 55, Annex, $\$$ II, paragraph (c):

In the event that power is conferred by law upon the aeronautical authoritics of the United States to fix fair and economic rates for the transport of persons and property by air on international services and to suspend proposed rates in a manncr comparable to that in which the Civil Acronautics Board at present is empowered to act with respect to such rates for the transport of persons and property by air within the United States, each of the Contracting Parties shall thercafter excrcise its authority in such manner as to prevent any rate or rates proposed by one of its carriers for services from the territory of one Contracting Party to a point or points in the territory of the other Contracting Party from becoming effective, if, in the judgment of the aeronautical authorities of the Contracting Party whose air carricr or carriers is or are proposing such rate, that rate is unfair or uneconomic. If onc of the Contracting Parties on receipt of the notification referred to in paragrapl (c) above is dissatisfied with the new rate proposed by the air carrier or carriers of the other Contracting Party, it shall so notify the other Contracting Party prior to the expiration of the first fifteen of the thirty days referred to, and the Contracting Partics shall endeavour to reach agreement on the appropriate rate. In the cvent that sucl agreement is reached each Contracting Party will exercise its statutory powcrs to give effect to such agreement. If agreement has not been reached at the end of the thirty day period referred to in paragraph (c) above, the proposed rate may, unless the aeronautical authorities of the country of the air carrier concerned see fit to suspend its operation, go into effect provisionally pending the settlement of any dispute in accordance with the procedure outlined in paragraph (G) bclow. 
ing an "open-rate" situation would be nonetheless obligated to allow the proposed rate to go into effect, pending arbitration..$^{64}$

The British motive in pressing for rate-fixing powers for the $C A B$ was apparently a feeling that the $C A B$ could be trusted more than Pan American to be "reasonable" in fixing "fair and economic" rates. ${ }^{05}$ Until the $\mathrm{CAB}$ received its expanded powers, the British reserved the right of summary action against rate wars instituted by American carriers. As a sign of good faith, Britain would rely on the CAB's discretion once it had obtained full rate control powers. ${ }^{\circ 0}$

The Bermuda Agreement contemplated that IATA normally would reach agreement on fares, and furthermore, that these fares would be approved by the governments whose carriers negotiated them. The reservation by states party to Bermuda-type agreements of the power to disapprove IATA tariff agreements was supposed to insure that IATA would conscientiously consider all nations' interests in the course of its fare deliberations. The provisions of paragraphs (c) and (f), by preserving sovereign powers to regulate fares directly, were expected to keep IATA "honest" but were not designed as practical means for habitual rate-setting by governments disgruntled with IATA. $A$ central problem since Bermuda is that the $C A B$ has not only been

64. Under Bermuda bilateral, Annex, § II, paragraph (घ), cither party an submit a dispute over a proposed rate to the ICAO for arbitration, whether or not the rate has provisionally gone into effect under paragraph (c) or (D). Although the ICIO's response is termed an "advisory report," each government pledges to "use its best efforts under the powers available to it to put into effect the opinion expressed in such report." Once the $\mathrm{CAB}$ obtains the rate-fixing power which will invoke paragraph (c), sec pp. 1149-52 infra, the ICAO's report would have a mandatory effect on the C.MB at least so long as $\$ 1102$ of the Federal Aviation Act remains in effect: "In exercising and performing [its] powers and duties under this Act, the Board .... shall do so consistenty with any obligation assumed by the United States in any treaty, convention, or agreement that may be in force between the United States and any other [sic] forcign country or forcign countries ...." 49 U.S.C. $\$ 1502$ (1970).

65. The invocation of paragraph (e) is contingent on the CAB's recciving the same powers "to fix fair and economic rates" for international services that it now" has for domestic services. Paragraph (h) provides that "the rates to be agreed in accordance with the above paragraphs shall be fixed at reasonable levels, due regard being paid to all relevant factors, such as cost of operation, reasonable profit and the rates charged by any other air carriers." Bermuda bilateral, supra note 55. Annex, $\$$ II, paragraph (h).

66. As a second quid pro quo, Britain refrained from demanding cxplicit controls of schedules and capacity, see $\mathrm{p}$. 1115 supra. The Final Act of the Bermuda Conference did speak, however, of a "fair and equal opportunity" for both countries' carricrs to operate flights between the two countries (Ihird and Fourth Freedom traffic) and an "understanding" that capacity on flights proceeding on to third countries (Fifth Freedom traffic) was to be limited to the legitimate requirements of long-haul, through service and would not attempt to divert traffic from local or regional services. Final $A$ ct of the Civil Aviation Conference, held at Bermuda, 15th Jan. to Ilth Feb., 1916, 19 4, 6, 60 Stat. 1512 (1946). The capacity principles of the Final Act were incorporated by reference in Bermuda bilateral, supra note 55, Annex, $\$ \S I$ and $V$, cf. note 60 supra. These capacity principles were incorporated in Articles 8 and 10 of the "Bermuda Form" bilateral in use since 1948 , cf. note 58 supra. Their ambiguity has remained potentially troublesome. See, e.g., McCarroll, The Bermuda Capacity Clauses in the Jet Age, $29 \mathrm{~J}$. AlR L. \& Cos. 115 (1963). 
left without the international rate powers required to invoke paragraph (e), but it has not even possessed, until very recently, the atlthority to exercise on behalf of the United States the rights of summary action allowed under paragraph (f). ${ }^{67}$

\section{E. The Chandler Fare Crisis}

The Board announced its approval of American carriers' participation in IATA immediately after the adjournment of the Bermuda Conference, ${ }^{88}$ and after some initial reluctance, it began routinely to

67. See p. 1145 infra.

68. The IATA resolution of October 1945 establishing the Traffic Conference system, see p. 1114 supra, was filed with the $\mathrm{CAB}$ pursuant to $\$ 112$ of the Civil Acronatitics Act, ch. 601, 52 Stat. 1004 (1938) (superseded by 49 U.S.C. $\$ 1382$ (1970)), see p. 1185 infra. Although the decision was not announced until a week after the close of the lier. muda Conference, IATA Traffic Conference Resolution, 6 CAB 639 (1946), the thrce members of the Board who attended the Bermuda negotiations had decided to approve the IATA resolution prior to the Bermuda Conference, id. at $646 \mathrm{n} .12$ (dissenting opin. ion). In granting tentative approval to American carriers' participation in $1 \Lambda \mathrm{TA}$ for one year, the Board emphasized its understanding that IATA's price-fixing would not extend to the allocation of schedules or capacities--the same understanding which the Ancrictin delegation at Bermuda had reached with the British. Id. at 640.41 cf. note 59 supra.

The decisions filed by the Board reflect with considerable prescience the conflicting values and abuses which IATA has displayed throughout the subsequent quarter century: The three veterans of Bermuda, Chairman Pogue and Members Ryan and Branch, placed heavy reliance in their majority opinion on the unanimity rule of the Traffic Conference as a guarantee of each carrier's ultimate freedom of action. Rather wishfully, they assumed that "an open rate situation may, and indeed should, exist if the rate proposals advanced at any conference are unreasonable or economically unsound and are not properly related to the reasonably attainable costs of the air carriers," id. at 615 .

The majority members of the Board also contended that their legitimation of the anti. competitive conference system was consistent with congressional intent. Section 412, they argued, obviously contemplated agreements between competitors, and was drawn from the similar provision in the Shipping Act of 1916 which had empowered the pertinent federal regulatory agency to approve or disapprove such agrecments. The Board could therefore see "no indications of reversal of [the] national policy thus revealed in the provisions of the Shipping Act and the Civil Aeronautics Act with respect to the rate con. ference method." Id. at 642. The fatal flaw in the analogy to shipping conferences, however, is that by customary accommodation, if not by right under international law, merchant ships of all nations can generally gain access to foreign ports. See M. McDoucst. \& W. BURKe, The PUBlic ORder of THE OCEANs 99, 103.17 (1962). Thus "tramp" shippers who refuse to conform to conference rates structures are not usually excluded from the international shipping trade by foreign governments interested in preserving certain price levels. See generally Note, Rate Regulation in Ocean Shipping, 78 HAkv. L. REv. 635-38 (1964). Under the accepted doctrine of national sovereignty of territorial airspace, airlines which persist in exercising their freedom of action by vetoing conference rates or withdrawing from IATA may be denied entry into pro-IATA countries. See p. 1102 supra. Thus the IATA conference system could be expected to be much more cohesive and comprehensive than the shipping conference system, where "tramp" steamers were an accepted fact of life.

In partial recognition of this fact, the majority noted that the present American car. riers were flying into Great Britain and France at government-proclaimed rates. IA $I A$ Traffic Conference Resolution, 6 CAB 639, 642 (1946). Given the limited powers of the Board, whatever influence the Board and American air carricrs could excrt through IATA was the only alternative (short of suspending transatlantic air service) to accepting unilateral rate control by foreign governments. Noting foreign fears of rate wars and international subsidy battles, the Board declared that controlled competition was the keystone of the public interest as defined by the Civil Aeronatics Act, id. 643.44, and concluded that the IATA conference system could not, at least initially, be held to be 
approve IATA tariff packages. ${ }^{63}$ Fares remained high and government subsidies were essential for all carriers. ${ }^{70}$

Persistent demands by American carriers for lower fares led in 1952 to the inauguration of tourist class service across the North Atlantic, at about seventy per cent of the first class fare. ${ }^{71}$ This sparked a substantial growth in passenger traffic, ${ }^{22}$ and by 1955 the American air-

contrary to this concept of the public interest. In closing, the Board asked for the full regulatory power over international aviation contemplated in the Bermuda agreement as the only way "to meet with full effectiveness the problems that will arise in international air transportation." Id. at 646 .

A vigorous dissent by the sole member of the Board not in attendance at Bermuda. Member Lee (one seat on the Board was then vacant, see 6 C.AB II (19H0)), altacked the Board's order as "an abandonment of the basic American economic principle of competition." IATA Traffic Conference Resolution, 6 CAB 639, 049 (1940). In his view, the conference system's unanimity rule would insure that fares were adjusted to the highest rather than the lowest-cost carrier. Id. at 649-50. The threat of a suspension of traffic rights would convince any over-aggressive competitor that he would do better to pocket his higher profit margins than to disrupt the whole system. In vicw of the Board's own disclaimer of "effective influence" over rates, and the apparenty secret nature of IATA's proposed Traffic Conferences, adequate review of IATA agreements would be impossible. IATA's promises of reduced rates in time had to be discounted by the fact that insulation from price competition discourages aggressive management. I.ITA would place a premium on wasteful non-price competition while reducing incentives to come up with cost-cutting innovations. Id. at 655 .

The dissent conceded that the fare controls of the British and French were perfecty legitimate acts of air sovereignty. Id. at 657. IATA could not, however, be expected to modify these expressions of national interests. Adequate powers to deter predatory practices by American carriers were vested in the Board through its control of subsidy payments and route awards. Id. at 660 . The provision in the Bermuda bilateral for appeal to the PICAO, see notes 43 and 64 supra, was sufficient protection against unilateral British rate-making. $6 \mathrm{CAB} 639,661$ (1946). This potentiality for inier-govemmental arbitration, claimed the dissent, made IATA unnecessary. The IATA conference system appeared to offer no advantages in persuading the Europeans to lower transatlantic fares, and sanctioning IATA would only allow price-fixing on other routes to countries which had not yet felt it necessary to assert their sovereignty over air fares. Id. at 658 .

69. Following the approval of the Traffic Conference machinery, the Board refused to approve the first tariffs produced by the IATA Traffic Conferences, on the grounds that no showing was made of the proposed fares' relation to the economic cost of providing air transportation. The Board declared that, lacking such information, it could not approve the fares. Resolutions of North Atlantic Traffic Conference, 6 CAB 845 (1946). The Board's problem arose from the fact that $\$ 412$ of the Civil Acronautics Act, ch. 601, 52 Stat. 1004 (1938) (superseded by 49 U.S.C. $\$ 1382$ (1970)). required it to approve the tariff agreement if "it does not find [the agreement] to be adverse to the public interest," see p. 1135 infra, yet the Act's definition of the public interest included "the promotion of adequate, economical, and efficient service by air carriers at reasonable charges ..." ch. $601 \S 2(\mathrm{c}), 52$ Stat. 980 (1988) (superseded by 49 U.S.C. $\$$ 1302 (c) (1970)), cf. note 161 infra. The Board conditioned continued approval of the Traffic Conference system on IATA's providing the Board with the minutes of these Traffic Conferences. Resolutions of North Atlantic Traffic Conference, $6 \mathrm{CAB} 845$, 848-49 (1946). This show of procedural scruples proved to have little substance, however. Despite IATA's continued failure to provide economic data or to show that such data were considered in the fare-setting process, the Board periodically extended its approval of the Traffic Conferences, IATA Traffic Conference Resolution, 9 CAB 221 (1948), and made its approval final in 1955, CAB Order No. E-9305, June 15, 1955. The failure of the Board to enforce its initial requirement that IATA provide the Board with eco. nomic data to justify its tariff agreements forms the Eighth Cause of Action in the Aviation Consumer Action Project's complaint against the CAB, see note 4 supra.

70. See Keyes, The Mraking of International dir Fares and the Prospects for their Control, 30 J. AIR L. \& Cox. 173, 175-81 (1964).

71. See, e.g., id. at 176-77; S. WHEATCROFT, supra note 11 , at 136.38 .

72. M. Straszheim, The International Airline INdustry 119-20 (1969); K. Pillat, supra note 43 , at 61 . 
lines were operating their transatlantic routes at a profit, exclusive of subsidies. ${ }^{73}$

The $\mathrm{CAB}$ chose this setting to attempt for the first time to force fares down through rejection of proposed IATA tariffs. The Board's refusal to approve a first-class fare hike effective in the spring of 1956 brought cries of impending chaos from European governments and resulted in the Board's retreat. ${ }^{74}$ The CAB's call for more economical service was answered by IATA after an interval lengthy enough to prove that IATA acted of its own volition. High density economy class fares, nearly thirteen per cent below existing tourist rates, were introduced over the North Atlantic two years after the 1956 debacle. This class proved so popular that tourist service was phased out.75

From 1948 through 1962, passenger traffic across the North Atlantic increased nearly 1000 per cent. ${ }^{70}$ First-class traffic actually decreased, however, so that ninety-one per cent of the 1962 traffic moved in economy class. ${ }^{77}$ The $\mathrm{CAB}$ made clear, prior to IATA's autumn 1962 Traffic Conference in Chandler, Arizona, that the obviously elastic economy class market should be cultivated by lower fares. ${ }^{78}$ IATA responded by cutting in half the existing ten per cent discount on round trip tickets, thus effectively raising the cost of air transportation for most travelers. ${ }^{79}$

The $\mathrm{CAB}$ disapproved this fare increase, noting the acute over-

73. M. Straszheim, supra note 72, at 176.

74. The fare agreements reached by IATA in the fall of 1955 called for a ten per cent increase in first-class fares on North Atlantic and transpacific routes, without any reduc. tion in tourist fares. The Board attacked what it felt to be the covert subsidization of luxurious first-class service by artificially high tourist rates. While approving North Atlantic tourist rates through December of 1956, with a strong argument for their reduction after that time, it disapproved the proposed first-class fares. Pan American World Airways, et al., IATA Agreements, 23 CAB 275 (1956). Forcign governments expressed shock at the Board's action, which came less than two months before the fares were to go into effect. The Board responded by temporarily approving the first-class fares through September 1956-the end of the summer peak travel season. See 1 A. CilAYES, Er. AL., supra note 59, at 514. The Board's chairman subsequently justified this change of hcart as a necessary sign of the Board's good faith. Hearings on Monopoly Problems, stupra note 4 , at 326 .

75. M. STRAszheim, supra note 72, at 120; R. DAviEs, supra note 15 , at 459.

76. M. Straszheim, supra note 72, at 272, table C.2.

77. Id. The first-class fare New York to London, which by British edict had becn $\$ 375$ in 1946 , cf. note 52 supra, fell to $\$ 325$ in 1948 , then rose to $\$ 500$ in 1962 . The econ. omy fare in 1962 was $\$ 270$. $1 d$. at 273 , table C-3.

78. See, e.g., 1960 CAB ANN. REP. 19; 1962 CAB ANN. Rep. 19. See also Hearings on S. 1539 and S. 1540 (International Air Transportation Rates) before the Senate Comm. on Commerce, 88th Cong., Ist Sess., Ser. 15, at 13 (1963).

79. See generally I A. Chayes, ET AL., supra note 59, at 524-75. The full ninety-onc per cent of transatlantic traffic moving in economy class was not affected by the reduc. tion in the round-trip discount, because many economy class seats were filled by passen. gers travelling on special group or excursion tickets. Nevertheless, the C.A.B. found that some forty-six per cent of total transatlantic traffic and fifty-nine per cent of total transpacific traffic was adversely affected by the round-trip discount reduction. Order E-19385, March 18, 1963, 38 CAB 1063, 1064. 
capacity problems on the Atlantic routes caused by the precipitate conversion of major carriers to jet equipment and deciding that higher fares would only compound this problem.80 American carriers were still making a slight profit across the Atlantic, and having received no information whatsoever as to the financial condition of foreign airlines, the Board was unable to conclude that existing fares were uneconomical. ${ }^{81}$

The European carriers had, in fact, suffered heavy losses in the immediate aftermath of conversion to jets, ${ }^{82}$ and European governments protested the CAB's action vehemently. ${ }^{83}$ Great Britain claimed the right under paragraph $(f)$ of the Bermuda bilateral to prevent American planes from entering Britain unless they charged the Chandler fares. ${ }^{84}$ The CAB "advised" American carriers to continue to grant the full, pre-Chandler round-trip discounts. ${ }^{85}$ The British thereupon threatened to impound any American aircraft entering Britain with passengers paying less than the Chandler fares. ${ }^{80}$ The other European countries remained united in support of Great Britain, likewise involing the powers left them under paragraph ( $f$ ) of their respective Bermuda-type bilateral air service agreements with the United States to decree that the Chandler fares were the only lawful fares which could be charged for flights entering their countries from the United States. ${ }^{87}$ The Board disregarded the British threats for two nervous days, during which the American airlines continued to charge the old IATA rates,

80. Order E-19291, Feb. 12, 1963, $38 \mathrm{CAB}$ 1068, 1070-71.

81. Id. at 1069 n.2; Order E-19385, Mar. 18, 1963, 38 C.1B 1063, 1064 (reaffirming the Board's decision, tentatively expressed in Order E-19291, supra note 80, to disopprove the IATA tariffs argeed upon at the Chandler Traffic Conference).

82. R. Davies, supra note 15, at 530; S. Whentcroft, Air Transrort Policy 101-02, 114-16 (1964); R. ThORNTON, supra note 31, at 1964 .

89. See 1 A. Chayes, ET AL., supra note 59, at 536-40.

84. See p. 1116 supra; cf. note 210 infra.

85. Letter from Robert Murphy, vice-chairman of the C.1B, to Willis Lipscomb, vice-president of Pan American World Airwajs, Inc., in 1 A. CilAyes, et AL, supra notc 59 , at 540 .

86. Testimony of Abram Chayes, Legal Advisor to the Dep't. of State, Hearings on S. 1539 and S. $15+0$, supra note 78, at 33-34. The British required American carriers to charge the Chandler fares by amending the carriers' operating permits to make operating authority conditional on the charging of the Chandler fares. Any flight entering Britain with passengers paying sub-Chandler fares was thus illegal, at least under British domestic law. Senator Magnuson, chairman of the Senate Commerce Committee, thought it significant that the British acted by the indirect means of amending American carriers' operating permits. The Senator avowed that the British had positive rate-making statutes which they might have used. Hearings on S. 1539 and S. 1570, supra, at 5. Senator Magnuson's conclusion that British use of the indireet method of fixing rates through amendment of operating permits legitimized retaliatory American action under $\$ 402$ of the Federal Aviation Act, 49 U.S.C. $\$ 1372$ (1970), cf. note 93 infra, failed to take account of the relative powers of the American and British judiciary in revictiing administrative orders, and of the liberal rules of American courts relative to forcign citizens standing to sue. See testimony of Alan Boyd, then Chairman of the CAB, Hearings on $S .153 y$ and S. 1540, supra, at 11; cf. letter of Chairman Boyd to Sen. Mlagnuson, id at 111-12.

87. Hearings on S. 1539 and S. 1570, supra note 78, at 34 . 
before acknowledging that it was powerless under the municipal law of the United States to exercise paragraph (f) powers or to compel American carriers to adhere to any given fare. ${ }^{88}$ The carriers promptly complied with the Chandler fare agreement, while the $\mathrm{CAB}$ set about explaining its failure to Congress.

\section{F. The Midsummer Flights Dream}

The Chandler fare crisis coincided with the release of President Kennedy's Statement of International Air Transport Policy. ${ }^{80}$ In accordance with that policy, and in response to the manifest impotence of the CAB vis-à-vis IATA and other governments, White Housedrafted bills giving the Board international rate-making powers were promptly introduced in both houses of Congress. ${ }^{00}$ Unfortunately, the hearings held on the bills in both the Senate ${ }^{91}$ and the House ${ }^{02}$ tended to concentrate on the short-term problem of what could have been done to avoid the American capitulation over the Chandler fares, rather than on the more fundamental issue of how to represent more adequately the American public interest in the IATA fare-setting forum.

There was much debate over the Board's power to suspend foreign air carriers' permits in retaliation for the threatened detention of American aircraft. ${ }^{93}$ The $\mathrm{CAB}$ and the State Department expressed

88. Id. at $29-30$.

89. Statement on United States International Air Transport Policy, White Hause Press Release, April 24, 1963, reprinted at 30 J. AIR L. \& Com. 76 (196-1).

90. S. 1540, 88th Cong., 1st Sess. (1963); H.R. 6400, 88th Cong., 1st Sess. (1969)." 'The White House letter of transmittal appears in Hearings on S. 1539 and S. 15.0, sttpra note 78 , at 129 .

The original Foreign Rate Study required of the CAA, the precursor of the CAB (see note 5 supra), by the Civil Aeronautics Act (see note 27 supra) concluded that pend. ing the acquisition of more "practical experience with rates in forcign air transportation" there was no "immediate need for the Federal Government to further regulate the rates, fares, and charges of air carriers engaged in foreign air transportation . . . ." CiviL

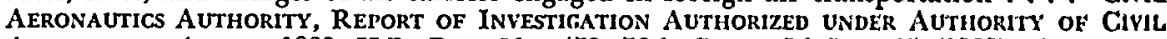
Aeronautics Act of 1938, H.R. Doc. No. 478, 76th Cong., 2d Sess. 15 (1939). loutr yeatrs later, the Board first requested international rate powers, $1942 \mathrm{CAB} \Lambda N N$. RE1'. 14 (1913). The request was repeated in $1944 \mathrm{CAB}$ ANN. REr., and, with the exception of the C.A.1B.'s annual report for 1966, has been reiterated anntally since the $1946 \mathrm{CAB}$ ANN. RE1. SCE also Hearings on H.R. 1716, H.R. 6400, and S. 1540, supra note 58, at 38 .

91. Hearings on $S .1539$ and $S .1540$, supra note 78.

92. Hearings on H.R. 1716, H.R. 6400 and S. 1540, supra note 58.

93. See, e.g., id. at 24, 68-69, 89-90; Hearings on S. 1539 and $S .1540$, supra note 78 , at $3-18,44,56$. Some argued that $\$ 402(f)$ of the Federal Aviation Act, 49 U.S.C. $\$ 1372(I)$ (1970), gave the $\mathrm{CAB}$ an indirect but potent means of controlling forcign rates. That section provides, in part, that "[a]ny permit issued under the provisions of this section may, after notice and hearing, be altered, modified, amended, suspended, canceled, or revoked by the Board whenever it finds such action to be in the public intercst." 40 U.S.C. $\$ 1372(\mathrm{f})(1970)$. The American scheduled carriers have long maintaincd that the Board has wide latitude in using $\$ 402(\mathrm{f})$, and have used this argument to blunt legislative efforts to give the CAB explicit rate powers. Sce Statement of Stuart Tipton, President 
their firm belief that such ad hoc action would not have been lawful under either the Board's delegation of power from the Congress or under the inherent power of the President, though many Senators rejected these disclaimers of authority. ${ }^{94}$

Congressional efforts to register disapproval of the Administration's conduct resulted in the demise of the international rate powers bills. Senatorial pique took the form of deleting provisions for cxecutive review of $\mathrm{CAB}$ international rate orders; once this action was taken White House support for the measure waned and, having passed the Senate, the bill died in House committee. ${ }^{95}$

Having failed once again to secure international rate-making power, the $\mathrm{CAB}$ began developing in the mid-sixties a different means of bringing pressure to bear on IATA. Non-scheduled "supplemental" carriers specializing in charter flights began to make major gains in the total transatlantic market after the charter industry was reorganized in 1961.96 Through lax enforcement of the affinity rules governing charter flights, the Board encouraged the growth of the supplementals'

of the Air Transport Association, Hearings on H.R. 1716, H.R. 6100, and S. 1510, supra note 58 , at $68,89-90$. Former Chairman Boyd of the $C A B$, however, read $\$ 402(1)$ as conferring the very narrow powers of quashing "destructive" behavior "inimical" to American interests and felt that a dispute about what was a reasonable rate, such as was involved in the Chandler fare crisis, was not within the compass of $\$ 102(1)$ 's suspension power. Hearings on S. 1539 and S. 1510, supra, at 8. Chairman Bojd's position is the more defensible, for the decision of the Congress in 1938 not to give the Board forcign rate powers would seem to mandate a conservative reading of the Board's poviers under $\$ 402(\mathrm{f})$. See Note, Regulation of International Aviation, 75 HARv. L. Rev. $575,584.85$ (1962). In any event, the passage of Pub. L. No. 92-259, see pp. 1135.36 infra, has rendered the dispute moot.

94. Hearings on S. 1539 and S. 1540, supra note 78 , at 18-19, 14.

95. As introduced, S. 1540 provided for presidential approval of any order by the CAB setting international air fares. S. 1540, 88th Cong., Ist Sess., \$ 2(b) (1963) reprinted in Hearings on $S .1539$ and $S$. 1570, supra note 78, at 133 . After first reporting $S$. 1540 favorably, S. REp. No. 473, pt. 1, 88th Cong., lst Sess. (1963), the Senate Commerce Committee issued a revised report in which $S$. 1540 was amended to exclude executive review, S. ReP. No. 473, pt. 2, 88th Cong., lst Sess. (1963). Although this move was presented as an effort at sparing the President a needless technical task, id. at 1, the amendment was apparently intended to serve primarily as an expression of Congressional disfavor with the Administration's "soft" line during the Chandler fare crisis. Interview" with a member of the Senate Commerce Committee staff, Oct. 19, 1971.

As amended, S. 1540 passed the Senate, 109 CoxG. Rra 22790 (Nov. 26, 1963). The removal of provision for executive review from $S$. 1540, plus the confusion caused by President Kennedy's assassination the day after S. 1540 as amended was reported out of Committee, cut off further White House support for the measure. After $\$$. 1540 died in committee in the House, fruitless efforts were made to revive the bill in the next Congress. H.R. 465, 89th Cong., Ist Sess. (1965); S. 907, 89th Cong., Ist Sess. (1965). Sec Hearings on H.R. 465 (International Air Fares) before the Subcomm. on Transporlation and Aeronautics of the House Comm. on Interslate and Forcign Commerce, 89ih Cong., Ist Sess., ser. 89-25 (1965).

96. Act of July 10, 1962, Pub. L. No. 87-528, 76 Stat. 143. See generally K. PiLtal, supra note 43, at 153-64; Hearings on Air Fares and Charter Service before the Subcomm. on Transportation and Aeronautics of the House Comm. on Interstate and Foreign Commerce, 91st Cong., 2d Sess., ser. 91-80, at 193, 273 (1970). For the history of charter activity prior to the 1962 Act, see Goldklang, Transatlantic Charler Polig:-A Study in Airline Regulation, 28 J. AIr L. \& CoM. 99 (1962); Note, Supplemental Air Transportation-Public Law $87-528,28$ J. AIR L. \& CoM. 453 (1962); and S. RICHMoNd, supra note 20, at 85-95. 
market share. ${ }^{97}$ In 1966, the Board authorized the supplementals to operate inclusive Tour Charters, which allowed travel agents to charter an aircraft and sell tickets to the general public as part of a vacation package of transportation, accommodations, and tourist services. ${ }^{p 8}$ This boon to the supplemental industry was bitterly contested by the scheduled carriers, and the Court of Appeals for the Second Circuit ruled that the Board had exceeded its powers. ${ }^{00}$ The Board was vindicated by Congress, however, which in 1968 amended the Federal Aviation Act to explicitly authorize supplemental carriers to opernte Inclusive Tour Charters. ${ }^{100}$ In addition to its support for American

97. The competition, both economic and political, between the scheduled carricrs and the supplemental carriers is extremely bitter. See, e.g., The Airlines Move 'Tou'ard Mass Travel, Bus. WeEk, Feb. 26, 1972, at 49. The CAB, subject as it is to the whole range of federal administrative procedure-law, already finds virtually cvery decision it makes affecting the balance between the "skeds" and the "non-skeds" challenged in court by the class of carrier adversely affected. See also Pilson, The Exemption Provision of tha Civil Aeronautics Act: The Problems Inherent in the Exercise of "pure" Administralive Power, 29 J. AIR L. \& CoM. 255 (1963). Thus spokesmen for the CAB can admit publicly to a pro-supplemental "tilt" only at the peril of eating their words in court. One such public admission came from CAB Chairman Alan S. Boyd after the Chandler farc crisis, when the $\mathrm{CAB}$ was anxious to establish its bona fides as a low-fare advocate:

[O]f course, we are encouraging charters to the extent we can. We are trying to draw a line, so we don't have the charters operate to an extent that they damage our regular route carriers. We don't want that.

But we are trying to use the charters as a means of bringing down the fares. It is

one method that the Board had adopted and has pursued to accomplish lower farcs.

Hearings on S. 1539 and S. 1540, supra note 78, at 28.

There is thus little but inferential evidence that the Board has been consciously lax in its enforcement of charter flight affinity rules. All it will admit publicly is that it is woefully understaffed to enforce adequately the convoluted affinity rules, which prescribc the qualifications and procedures which a given group of travellers must satify in order to charter an aircraft. See 14 C.F.R. Parts 207, 208, 212, and 214 (setting forth scparate sets of charter regulations for, respectively, U.S. scheduled air carriers, U.S. supplemental air carriers, foreign scheduled air carriers, and foreign charter air carriers). Prior to April 6, 1971, the charter regulations set forth at 14 C.F.R. Parts 207, 208, 212, 214, and 295 were not even consistent. See Notice of Proposed Rule Making, May 8, 1970, 35 Fed. Rcg. 7587 (proposing to repeal Part 295 and make the remaining parts substantially identical, adopted, Jan. 29, 1971, 36 Fed. Reg. 2482 et seq.). The CAB's complaints that it is unable rather than unwilling to enforce these charter rules, see, e.g., Hearings on Air Fares and Charter Service, supra note 96 , at 43 , must be read in the light of the fact that the CAB itself promulgated the unenforceable rules. As the furor over "black market" charters hats mounted, spurring the CAB to take selective action against a few violators, sce, e.g., N.Y. Times, Aug. 31, 1971, at 66, col. 1; id., Sept. 18, 1971, at 57, col. 1; Wall St. J., Scpt. 20, 1971, at 11, col. 5; N.X. Times, Oct. 9, 1971, at 62, col. 5, the CAB has proposcd revising its charter regulations so as to remove the affinity requirement for groups who charter an aircraft six months or more prior to departure. This proposal has been received very favorably by the charter industry, and seems indicative of the Board's underlying sympathies. See Advance Notice of Proposed Rule Making, Jan. 29, 1971, 36 Fed. Reg. 2514 (1971); Notice of Proposed Rule Making, Dec. 30, 1971, 37 Fed. Reg. 222 (1972).

98. Supplemental Air Service Proceeding, Docket No. 13,795, Order No. E-23950, March 11, 1966. Regulations governing Inclusive Tour Charters were issued as 14 C.F.R. 1art 878, 31 Fed. Reg. 4779 (1966). See $X_{\text {. }}$. PIllai, supra note 43, at 164.65.

99. Pan American World Airways, Inc. v. C.A.B., 380 F.2d 770 (2d Cir, 1967), aff'd by an equally divided Court sub nom. World Airways, Inc. v. Pan American World Airways, Inc., 391 U.S. 461 (1968) (per curiam).

100. Act of Sept. 26, 1968, Pub. L. No. 90-514, 82 Stat. 867. The CAB's regulations issued pursuant to the Act have imposed limitations on the types of ITC flights which the charter 
charter airlines, the Board has also been liberal in granting permits to the increasing number of foreign charter carriers seeking operating rights to the United States.101

Helped by fortuitous factors as well as the scheduled carriers' own mistakes, the charter operators have in the past two years become a serious problem for IATA.102 The first signs of cracks in the IATA edifice came in the spring of 1971, when SABENA, the Belgian national airline, announced reduced youth fares for the peak summer travel season. The Belgian government, which owns over half of SABENA's stock, took advantage of the standard clause in IATA tariff agreements permitting a carrier to break such an agreement upon the orders of its flag government. ${ }^{103}$

As was demonstrated by the Chandler fare crisis, successful European resistance to American fare reductions is dependent on European unanimity. ${ }^{104}$ The relative proximity of the gateway cities of Europe insures that, should one nation reduce fares on its flag carrier for the

carriers may offer. See 14 C.F.R. Part 378 (1971). The Senate recently held hearings on proposed legislation which would remove most of these restrictions. See S. 3513, 92d Cong., 2d Sess. (1972) and N.Y. Times, May 7, 1972, § 5, at 29, col. 1.

101. See Testimony of Secor D. Browne, Chairman of the CAB, Hearings on Air Fares and Charter Service, supra note 96 , at 8.

102. Three factors besides the $\mathrm{CAB}$ have helped the charter operators gain strength. First, the winding down of American military activity in Southeast Asia reduced the demand for chartered troop-carrying airliners. Military traffic had been the staple of the major American supplemental carriers during the middle sixties, serving to finance the transition of the supplementals to jet equipment. Hearings on Air Fares and Charter Service, supra note 96, at 193, 269, 273. As military traffic decreased, this equipment was released to serve the transatlantic charter market. Friedlander, The New Low Air Fares v. Bureaucracy, N.Y. Times, July $11,1971, \$ 10$, at 35 , col. 1 . This extra capjcity drove down transatlantic charter fares, attracting legions of charter passengers. Hearings on Air Fares and Charter Service, supra, at 323-24; N.Y. Times, June 1. 1971, at 1, col. 1. Second, scheduled airline managements repeated their errors of a decade carlicr, purchasing new $\mathbf{7 4 7}$ aircraft with the same unseemly haste that marked the introduction of jet equipment in the late fifties. See S. Wheatcrort, supra note 82, at 94. These clficient new jumbo jets made existing jet equipment redundant, causing a glut of old jets on the used aircraft market. See, e.g., Altschul, Which Way for the Airlines?, B.Ankov's, March 6,1972 , at 5, 19. These jets have been snapped up by charter operators at bargain prices; while not as efficient as jumbo jets when both carry fult loads, a fully-filled chartered "old" jet offers per passenger costs far below a half.filled jumbo jet. Comparative cost data for jumbo and standard jets appear in Hearings on $\$$. $2+23$ (Regulation of Rales and Practices of Air Carriers and Foreign Air Carriers) before the Subcomm. On Aviation of the Sen. Comm. on Commerce, 92d Cong., lst Sess., ser. 92-40, at 233-34 (1972). Sce also IATA Cost Committee Report, Hearings on Air Fares and Charler Service, supra note 90, at $61-119$.

Third, the recession of the American economy has decreased traftic growth, especially on the transatlantic routes, so severely that the new 747 's have not been able to profit from their increased efficiency because of under-utilization. The excess capacity caused by more 747 seats and less American traffic have made the scheduled airlines that much more vulnerable to diversions of traffic by the supplementals. See Hearings on $S$. 2423, supra, at 196-97.

103. For Belgium's majority control of SABENA, see, e.g., Hearings on S. 2f23, supra note 102 , at 183 . The exculpatory clause is discussed in N.Y. Times, June $1,197 \mathrm{I}$, al 1 , col. 1 .

104. Cf. pp. 1121-22 supra. 
flight from the United States to its capital, the other states will follow suit or see a substantial diversion of traffic from their own airline and airports. As long as rough equality prevailed in regard to the fortunes or misfortunes of the European lines, European solidarity persisted. The impact of the charter boom did not fall equally, however. London, Paris, and Amsterdam got their share of charters, but few went to Brussels. A few miles away, however, Luxembourg received thousands of tourists as the European terminal of cut-rate Icelandic Airlines. ${ }^{105}$ The squeeze was apparently strong enough to convince the Belgian government that severe measures were necessary to gain a bigger share of the gateway city business for Belgium. On April 27, 1971, SABENA gave the $C A B$ thirty days' notice of a round-trip fare of $\$ 200(\$ 220$ peak season) from New York to Brussels, for those aged twelve to twenty-nine. Existing IATA fares ranged from $\$ 596$ return economy class to $\$ 357$ for the lowest cost excursion ticket. By midsummer SA. BENA's fare had been matched by all the scheduled transatlantic carriers. ${ }^{100}$

This latest wrinkle was added to an already convoluted IATA fare structure which attempts to underbid the charter airlines for the excursion market while maintaining inflated fares for the captive market of short-term travelers. ${ }^{107}$ The discord over the summer youth fares precipitated a stormy six weeks' IATA Traffic Conference in Montreal. The revised IATA fare agreement which emerged from Montreal was then vetoed by the German national airline, Lufthansa, which denounced the latest promotional fares as too low and too complex. ${ }^{108}$

105. Icelandic Airlines, the only non-IATA scheduled airline crossing the North $\Lambda t$. lantic, was founded in 1944 as a private venturc. Iceland and the United States signcd a bilateral air services agreement in 1945, prior to the Bermuda Conference. Air Transport Services Agreement with Iceland, Jan. 27, 1945, 59 Stat. 1464, E.A.S. 463. Icelandic Airlines has thus been able to serve the United States without adhering to 1ATA prices, despitc years of harassment by European governments and the scheduled airline lobby within the United States. Icelandic's sole European friend has been Luxembourg, which gathers a share of the European tourist trade through service as Icelandic's gateway city. Icclandic has usually keyed its prices to IATA's, offering about a ten per cent discount, which, considering the location served within Europe and the older cquipment which Icelandic used to operate, served to keep Icelandic profitable but did not threaten the cxistence of any IATA carriers. Icelandic's service disadvantages have been minimized in recent years by Icelandic's acquisition, along with the charter carriers, of the surplus jets sloughed off by the major scheduled carriers, cf. note 102, supra. The improvement in Icelandic's service has led to new efforts to limit its operating rights to the United States. Although the bilateral agreement with Iceland still stands, threats of its rencgotiation served to win Iceland's assent to a limitation on Icelandic Airlines' capacity to 2.5 per' per cent of total United States-Europe scheduled capacity. Modus vivendi affected by ex. change of notes, June 24, 1970, [1970] 2 U.T.S. 1363, T.I.A.S. No. 6891. See generally M. STRASzheiM, supra note 72 , at 53-55; R. DAvies, supra note 15 , at 459 .

106. N.Y. Times, June 1,1971 , at 1 , col. 1 ; id., June 20, 1971, $\S 4$, at 8 , col. 1 ; $i d$., July 3,1971 , at 50 , col. 1 .

107. See S. REl. No. 92-593, 92d Cong., 1st Sess., at 15 (1972).

108. N.Y. Times, Aug. 13, 1971, at 1, col. 1. See generally Hoffman, The Great Air Fare War and What It Means to You, N.Y. Times, Dec. $5,1971, \S 10$, at 1 , col. 1. 
Lufthansa then proposed even lower but less restrictive fares which curried consumer favor while provoking charges of predatory pricing from Lufthansa's American competitors. ${ }^{100}$ After months of anticipation, tourists' hopes of a fare bonanza were frustrated by an intra-IATA compromise which eliminated some restrictions on the promotional fares while retaining the existing disparity between the cost of the general and promotional fares. ${ }^{110}$

This retained disparity suggests that the entire fracas turned on finding the best means of eliminating the CAB-fostered charter carriers and returning the scheduled carriers to their earlier pricing hegemony. As long as cheap charter flights remain the only effective means of depressing IATA fares, IATA carriers may again decide to seek the quick elimination of charter carriers through the temporary introduction of below-cost, "predatory" fares. Already the cracks papered over by the 197I IATA compromise have shown signs of reemerging, again in the form of fares designed to lure away the charters' summer staple, the youth market.111

\section{The Dysfunctional Interaction of IATA and the CAB}

\section{A. The Politics of IATA}

The International Air Transport Association was initially given ratemaking competence in order to protect European airlines from the low fares which only American airlines could economically offer. ${ }^{112}$ The expectation at Bermuda was that the $\mathrm{CAB}$ would obtain international rate-making authority for itself, insuring that any deviation of IATA from its intended function could be reviewed at a political level.113 The failure of Congress to grant such authority to the $\mathrm{CAB}$ has allowed IATA to continue to set rates which bear little apparent relation to the economic cost of providing air transport, long after the United States has disavowed the short-term policy of economic protection which secured American agreement to IATA in 1946.114 This situation is best

109. Hearings on S. 2423, supra note 102, at 14, 59, 213.

110. Wall St. J., Nov. 22, 1971, at 9, col. 3.

111. See Wall St. J., March 6, 1972, at 2, col. 3; Fricdlander, The Politics of Youth Fares, N.Y. Times, April 23, 1972, \& 10, at 39, col. I. Also, some IATA carriers are rumored to be engaged in under-the-counter discounting of blocks of seats on scheduled flights. Wholesale travel "consolidators" resell these seats individually to the general public. Interview with a staff member of the Senate Commerce Committee, May 12, 1972.

112. See pp. 1111,1114 supra.

113. See p. 1117 supra.

114. See Statement on United States International Air Transport Policy, supra note 89; Statement of International Air Transportation Policy, White House Press Relerse, June 22, 1970, reprinted at $36 \mathrm{~J}$. AIR L. \& CoM. 651 (1970). See also Hearings on H.R. I716, H.R. 6400 , and S. 1540 , supra note 58 , at $21 \%$. 
illustrated by a quarter-century's experience with IATA pricing policies across the North Atlantic, the most lucrative international aviation route in the world. Although the European air carriers have achieved the size and operating efficiency necessary for effective competition with American carriers, corresponding reductions in the overall cost of air transportation have not been realized, ${ }^{115}$ despite repeated calls for lower fares by the United States government. ${ }^{116}$

Although IATA likes to refer to itself as a private trade organization, working out fare agreements through apolitical compromises among business-minded airlines, ${ }^{117}$ this characterization is only partly truc. With the major exception of the United States carriers, most major international airlines are wholly or predominantly government-owned. ${ }^{118}$

115. For figures on the relative efficiency of American and foreign international carriers, see M. STraszheim, supra note 72 , at $167-68 ; \mathrm{K}$. Pillat, supra note 43 , at 59 . The level of IATA fares across the Atlantic is discussed at note 128, infra. Transpacific fares are discussed at note 122 , infra.

116. See, e.g., $1966 \mathrm{CAB}$ ANN. REP. 28; For CAB demands for transpacific rate reductions, see, e.g., 1969 CAB ANN. REP. 25.

117. See S. Cohen, IATA: The First THREe Decades 96 (1919):

"[M] uch of IATA's effort has had to be spent upon unglamorous and unreward. ing matters. The spectacular achievements of air transport have been those of its member airlines: none of IATA's accomplishments have ever created great public excitement and, probably, little that IATA may do in the future will cause much more. ... .

IATA's great importance, therefore, lics in the fact that it has been the vehicle of ... joint effort. As such, it has served, rather than controlled. It has admitted no politics...."

Mr. Cohen was writing as Public Relations Officer of IATA. After yet another decade of IATA, Mr. Cohen, again in his official capacity, was ready to admit that $I A T A$ might occasionally become entangled in politics-but only when external political forces inter. fered in IATA's otherwise business-oriented negotiations. See Cohen, Crisis in the Con. ferences, 27 J. AIR L. \& CoM. 150, 152-54 (1960):

To be quite precise, the airlines meet in the [Traffic] Conferences to work oitt recommendations for fares and rates to be charged on international services. These recommendations have no force in themselves: they must be carried back by airlines to their own governments for individual review and approval before they can be. come effective.

The airlines are not necessarily in the Conference because they want to bc, but because their governments insist that international fares and rates be governmentally agreed and realize that the airlines must have a voice in framing thom ....

Fare negotiations ... involve a wide variety of factors. There is not only the cost of providing the service. One must also take into account the cost of selling it, the traditional charges of competitive means of transport and the commercial risks of promotional pricing. On these factors and many others like them managements stake their own heads, their stockholders' money and their companies' existence. Most governments have felt strongly that these are outside the proper competence of the ordinary civil service and have therefore delegated the task of working out the pat. terns of fares and rates to the airlines in the Conference. But they retain the right to review and disapprove-which they exercise in the public interest. Make no mistakeIATA Conferences may propose, but governments dispose.

... It has been said that the Conference system throttles competition: actually, it gives competition a chance to work itself out on paper, instead of through the costly methods of the marketplace ....

See also Cohen, Confessions of $a$ Former IATA Man, 34 J. AIR L. \& Com. 610 (1968).

118. See R. ThorNTon, supra note 31, at 8 table 1; Statement of Knut Hammerskjold, Director-General of IATA, Appendix B, in Hearings on S. 2423, supra note 102, at 181. 
The fact that government ownership is the norm in the international airline industry has two principal effects on the expression of national interests in international aviation. First, with government capital at stake, the development of national commercial air power is viewed by most states not in terms of the well-being of an entire system, but rather in terms of the financial fortunes of a specific carrier. Second, the representatives of this specific carrier at IATA Traffic Conferences will in effect be government spokesmen.

The essential function of de facto government participation in IATA Traffic Conferences has been the suppression of IATA's economic behavior qua cartel in favor of political behavior in the manner of a multilateral conference of governments. IATA is an imperfect cartel ${ }^{119}$ whose agreements are subject to the veto of any scheduled carrier authorized to operate by an ICAO member country. ${ }^{120}$ This circumstance should make agreement on tariffs contingent on the economic viability of the rates proposed in the tariff agreement for every carrier concerned. As a matter of rational, profit-maximizing economic behavior, the insistence by an inefficient airline on high fares should provoke an open-rate situation. Efficient carriers would propose low fares designed to increase their share of the available traffic by driving the inefficient carrier out of business, while simultaneously reaching previously untapped portions of the air transportation demand curve. The inefficient carrier's veto would prevent IATA agreement on these low fares, but in the absence of IATA agreement the efficient carriers would file their low fares individually.

Acting on its own, the government whose inefficient carrier was thus attacked might choose to underwrite its inefficiencies through subsidies, or at least to exercise its paragraph $(f)$ powers by setting the fares

119. See T. JoRdan, Airline Regulation in AMerica 5.6, 226-33 (1970). Essential to an economic understanding of IATA is the fact that the Traffic Conferences confer monopoly powers over prices upon what is otherwise an oligopoly. While the price of a service is fixed among its principal suppliers, total revenues are not allocated among suppliers according to any agreement but are instead left to non-price market forces. That is, while price competition is eliminated, other forms of competition remain to affect the distribution of revenue among the carriers. I.ATA has sought to control some forms of non-price competition, such as in-flight food and entertainment, but other forms of competition, such as advertising, frequencies and schedules of nights, and the type of aircraft used have remained bejond IATA's control. See F. THAYER, supra note 22 , at 288-93; K. PILlaI, supra note 43, at 66. The most effective forms of non-price competition have proven to be frequent flights and advanced-design aircraft. The combination of additional flights and larger, faster aircraft has created a persistent problem of overcapacity. F. ThaYer, supra, at 291-92; M. Straszheiar, supra note 72 , at 105.07 . This exces capacity, by lowering the "load factor" or percentage of seats filled per flight, raives the proportionate share of the costs of a flight which each passenger must pay. Thus IATA may tend to maximize revenue without maximizing profit, because average costs are increased by the imperfect nature of the cartel.

120. See p. 1114 supra. 
for flights directly to and from its own territory-its Third and Fourth Freedom traffic-at a level high enough for its carrier to survive on that traffic alone. In practice, however, states with nationally owned international airlines have strengthened their positions through more complex alignments of power within IATA. Those states with a common interest in thwarting IATA's economic behavior have implicitly agreed to act in concert should an open-rate situation actually materialize. This concerted action allows a state to protect its high fare policy during an open-rate situation not only by setting the price of its individual Third and Fourth Freedom traffic, but also by controlling the price of its Fifth Freedom traffic-traffic which never actually crosses its own borders. By pooling their sovereign prerogatives to fix the legal fares at which commercial flights may enter and leave each of their countries individually, contiguous states can effectively control the price of air transportation to or through any one of their number. Absent such agreement, their individually-set, artificially inflated Third and Fourth Freedom fares would be subject to fatal collateral attack from a neighboring country which might allow lower fares to be charged on its Third and Fourth Freedom traffic. ${ }^{121}$

While the IATA bloc technique may be available to others, ${ }^{122}$ it is

121. Any country has a sovereign right to set fares on flights leaving or cntering itThird and Fourth Freedom traffic. But such a right may not confer much cffective power over rates if passengers can fly much more cheaply into a contiguous state and then cross into the high-fare country. Thus if state $A$ wants to maintain a high fare on the route $C$ to $A$, and has not agreed to do otherwise its bilateral air service agreement with $C, A$ can prescribe and enforce under its municipal law the fare to be patil for air travel from $C$ to $A$. Neighboring state $B$ may also have air service from $C$, though perhaps at a much lower rate. Unless $A$ cares to. set the rate for transit from $B$ to $A$ cqual to the difference in the rates charged for travel $C$ to $A$ and $B$ to $A$, or to institute a taxing system which has the same effect, most traffic from $C$ to $A$ will flow $C$ to $B$ to $A$. If, however, $A$ can control the fare on route $C$ to $B-$ a routc which if flown by $A$ 's alr. line is a Fifth Freedom route for $A-A$ can enforce its $C$ to $A$ fare policy.

The easiest way for $A$ to control the $C$ to $B$ fare is to make a deal with the govern. ment of $B$. By co-ordinating their regulation of their respective routes $C$ to $A$ and $C$ to to $B, A$ and $B$ can achieve their muttal rate regulation goals. Of coursc, unless their aims are identical, $A$ and $B$ will have to compromise to some extent. Were such compromises elevated to the formality of agreements binding under international law, thereby platc. ing restraints on the sovereign discretion of both $A$ and $B$ in setting rates on their direct routes from $C$, this negotiation of a compromise fare would be a quintessentially diplo. matic task. Yet such compromises, albeit in informal form and with independent rights of action preserved through an exculpatory clause allowing a government to order its carrier to bolt the IATA fare agreement, see p. 1125 supra, are the raison d'etre of IATA Traffic Conferences. The unanimity displayed by IATA states in opposition to American disapproval of IATA fares suggests that, at least vis-a-vis the United States, IATA itself functions as a multilateral conference of governments.

122. Transpacific rates have, in the CAB's opinion, been too high for a decadc or more. See Hearings on H.R. 465, supra note 95, at 27, 39; Hearings on S. 2123, stupra note 102, at 18. Because no contiguous states with air service to the United States border on those countries principally served by the transpacific routes-Japan, Australia, Hong Kong-high fare countries such as Japan have been able to enforce their farc policies through control of the fares on flights directly to and from their countries, without 
the Europeans who have perfected this means of resisting American low fare initiatives. The United States is particularly vulnerable to such collective action because of its anomalous position as (1) the source of by far the greatest number of IATA passengers, ${ }^{123}$ (2) the one major nation without de facto government representation within IATA, and (3) a nation which has not provided under its own municipal law any means of setting fares for its own Third and Fourth Freedom traffic. American affluence enables great numbers of United States citizens to travel abroad. America's ancestry encourages great numbers of Americans to vacation in Europe. This has made the North Atlantic route the most lucrative in international aviation.124 The United States has been liberal in granting access to this traffic: ${ }^{225}$ nincteen IATA carriers serve the route. ${ }^{126}$ In spite of consequent problems of over-capacity, ${ }^{12 i}$ fares on the route have generally remained at uneconomically high levels, ${ }^{128}$ providing concealed subsidization of for-

having to secure Fifth Freedom protection through IATA. Cf. note 175 infra. However. as advocates of high fares in the face of American resistance, the major acronautical countries of the Pacific basin have always sided with the European countrics in transatlantic fare disputes.

123. R. THORNTON, supra note 31 , at 59 table 5 .

124. M. Straszheim, supra note 72, at 43, 177; R. DAvies, supra note 15, at 472 .

125. See F. ThAYER, supra note 22, at 78-79; see also R. DAvies, supra note 15, at 457 . figure 75 and table 39 .

126. K. Pillal, supra note 43 , at 58 .

127. F. THAYER, supra note 22 , at 292.

128. The rash of promotional fares in recent years has done little to lower the level of basic fares-economy and first class fares without time or packige-deal limitations. As of 1964 , only thirty-four per cent of North Atlantic traffic was tourist travel. The remaining sixty-six per cent was a "captive market" of private and business travellers who lacked the flexibility to conform to the stringent requirements of IAT.A promotional fares. See K. PillaI, supra note 43, at 62-64. But see Hearings on S. 2423 , supra note 102, at 203 (testimony of Najeeb Halaby, former President of Pan American, estimating eighty per cent tourist traffic and twenty per cent "non-discretionary" traffic). These "captive" travellers have had to pay the basic fares. Since IAT A carricrs are extremely secretive about their operating costs, see id. at 53-60, cf. note 69, supra, it is impossible to determine whether IATA basic fares are economic in the sense of providing a "fair return" over costs in terms of a percentage of invested capital. Of course, these costs alone would not reveal the reasonableness of IATA fares, for the costs themselses are increased by IATA-fostered inefficiency. Cf. notes 68 and 119 supra. The basic disagrement beween the $\mathrm{CAB}$ and foreign governments has been whether lower fares, by providing an incentive for cost-cutting while attracting more passengers, would increase the net reventies of most airlines. The CAB's "Iow fare philosophy," which American carriers claim they share, see Hearings on $S$. 1539 and $S$. 1540, supra note 78, at 51, but c/. note 207, infra, is supported by a comparison of basic IATA fares with basic fares for domestic American routes of similar distance, flown by similar aircraft. See $\mathrm{R}$. THonstos, supra note 31 , at 208-10 tables 11-13, and K. PILLAI, supra note 43, at 109-11. See also Statement of K.G.J. Pillai, Executive Director, Aviation Consumers Action Project in Hearings on $S$. 2423 , supra note 102 , at 225-32.

Present fares support the finding in R. THornton, supra at 211, that YATA fares are generally higher than comparable domestic fares in the United States. The travel agent's boast that it is now cheaper to fly from the East Coast of the United States to Europe than it is to California is true only of the highly restrictive and seasonal excursion fares which the transatlantic carriers have adopted to meet the charter carricrs' competition.

As of May 1, 1972, the basic (one-way, coach class, without scasonal variations) fare for the 2704 miles from Boston to San Francisco, the longest domestic trunk route, vas 
eign carriers. Some carriers apparently feel that they could not profit from the increased traffic which would be created by lower North Atlantic fares. ${ }^{129}$ American carriers, the traditional leaders in excess capacity on this route, ${ }^{130}$ have had the most incentive to generate traffic growth through lower fares. Nevertheless, they have had only modernte success. European carriers have generally remained united in opposition to lower fares, especially lower basic fares, ${ }^{131}$ and as governmentcontrolled carriers, they have had the threat of a multilateral Fifth Freedom price fix to back them up.

European unity is essential in this regard-due to the facility of

$\$ 157.41$ (plus $\$ 12.59$ federal tax), yielding to the carrier 5.82 cents per mile. The basic fares (one-way, economy class) for the 3456 miles from New York to London on an IATA carrier were $\$ 242.00$ (\$295.00 peak season), for a cost of 7.00 (8.54 peak season) cents per mile, despite the fact that the longer length of the London flight allowed the fixed costs incident to a flight of any length to be pro-rated across twenty-five per cent more miles flown than on the San Francisco flight. An excursion traveler who happened to be golng to London for more than twenty-eight but less than forty-six days, and who otherwise could conform his plans to the sixteen lines of fine print in the OFficial AikLine Guive', might indeed fly to London and back for $\$ 240.00$, at a cost of only 3.47 cents per mile, unless he was traveling during the peak summer season, when he would have to pay $\$ 313.00$, or 4.53 cents per mile. The excursion fare from Boston to San Francisco and return, requiring a stay of seven to thirty days and not permitting travel on Fridays or Sundays from two in the afternoon to twelve midnight, was a year-round $\$ 236.11$ (plus $\$ 18.89$ federal tax), or 4.37 cents per mile.

The differential found by Professor Thornton for transpacific fares remains extremcly high. For the 3460 miles from Anchorage to Tokyo, it cost, effective May 1, 1972, $\$ 375.00$ one-way economy, or 10.84 cents per mile. There were no seasonal variations for either the basic fare or the excursion fare of $\$ 544.00$ round trip, requiring a stay of fourteen to twenty-one days, at a cost of 7.86 cents per mile. On the longer and more heavily traveled San Francisco-Tokyo route, the one-way economy fare was $\$ 417.00$, or 8.10 per mile for the 5149 mile trip. The round trip excursion fare of $\$ 709.00$ cost 6.88 cents per mile.

These fares and milages were compiled from Officiat Airline Guide, May 1, 1972 (North Amer. ed.) at 17 (excursion restrictions), 19 (mileage), and 565 (farcs); OFficint AIRline Guide, May 1, 1972 (International ed), at 8 (excursion restrictions), 439, 810, and 825 (fares and mileage). Cf. R. Thornton, supra at 210 table 13.

129. Among the inefficiencies which may deter some airlines from agrecing to Amcrl. can low fare initiatives are deficiencies of scale, see $R$. THonNTon, supra note 31 , at $110-17$, or the burden of providing service on strategic but uneconomic routes. See $i d$. at 42, 121, 132; Hearings on H.R. 1716, H.R. 6400, and S. 1540, supra note 58, at 217.

High fares also provide a net foreign exchange benefit to foreign countries by kecping down the currency outflow which would follow from expanded travel to North America by foreign nationals. Across the Atlantic, for instance, Americans have for the last decade constituted between sixty and seventy per cent of the passengers, while American airlines have carried less than fifty per cent of total transatlantic passengers. See Hearings on $S .2423$, supra note 102, at 13, and the figures given in Hearings on $S .1539$ and $S$. 1540, supra note 78, at 99, and Hearings on S. 3197 and S. $319 S$ (Strengthen U.S.Inter. national Air Transportation) before the Aviation Subcom. of the Senate Commerce Comm., 89th Cong., $2 \mathrm{~d}$ Sess., ser. 89.60 , at 15-16, 19 (1966). The high fares which make transatlantic air travel unnecessarily costly to Americans also serve, because of generally lower income levels, to deny such travel altogether to many Europeans. Although lower fares might entail no loss of profit to airlines because of the additional traffic gencrated, they would alter the proportion of non-Americans purchasing air transportation by mak: ing international air travel available for the first time to the European middle class.

130. See the figures given in Order E-19294, Feb. 12, 1963, 38 CAB 1068, 1070.

131. See S. REP. No. 95-593, 92d Cong., 2d Sess. 15 (1972). Basic fares are those for the cheapest class of travel, usually designated as "economy class," unencumbered by restric. tions on time of travel or length of stay. For most purposes the basic fare can be cont. sidered the cheapest one-way fare between two cities. 
intra-European transportation, any one major government allowing its carrier to join with the North American carriers in providing low-rate service during an open-rate situation would create a considerable diversion of traffic from the other European carriers. ${ }^{132}$ As long as no European country appears ready to give ground, however, the American carriers have remained chary of provoking an open-rate situation by vetoing IATA tariff agreements. ${ }^{133}$ The long-haul operations of the American carriers in particular are economically dependent on Fifth Freedom traffic picked up in Europe. ${ }^{13 *}$ Under the Bermuda agreement this traffic is subject to vague restrictions. ${ }^{135}$ Should an American carrier veto a rate agreement, retaliatory restrictions might be attempted-a risk which deters American carriers from pressing without restraint for lower general transatlantic fares so long as their overcapacity represents merely unrealized profits rather than actual losses. ${ }^{136}$

\section{B. Present Powers of the $C A B$}

As currently constituted, the international legal process for the regulation of air fares operates to the disadvantage of the United States. This disadvantage has been caused in large part by the impotence of the $\mathrm{CAB}$ in the international arena. Although the dichotomy between the Board's domestic and international powers to protect the American public interest was only tentatively established in 1938,137 it has remained a dead hand on American international aviation policy ever since. ${ }^{138}$

The prototypical Bermuda bilateral was predicated on the Board's receipt of international powers commensurate with its existing plenary authority over domestic air transportation. The implications of this feature of our international airline rate-setting agreements can

132. See Thornton, Power to Spare: A Shift in the International Airline Equation, 36 J. AIR L. \& CoM. 673, 676 (1970).

133. See K. Pillai, supra note 43, at 70-72.

134. M. Straszheim, supra note 72, at 208-09.

135. See note 66 supra. See also Hearings on H.R. 1716, H.R. 6100, and S. 1510, supra note 58 , at $28-29$.

136. This was the case in 1963. The revenue figures for American carriers published by the $\mathrm{CAB}$ in its order making final its disapproval of the Chandler fares show a low but not a losing rate of return for the transatlantic route. Order E-19385, March 18, 1963, $38 \mathrm{CAB} 1063,1064$. This may account for the failure of the American carriers to veto the Chandler fares at the Traffic Conference.

137. Civil Aeronautics Act of 1938, ch. 601, 52 Stat. 973 (repealed by Federal Aviation Act of 1958, 49 U.S.C. 1301 ff. (1970)). See also pp. 1108-09 supra.

138. Cf. note 95 supra. Rep. John F. Kennedy of Massachusetts introduced H.R. 2911, 81st Cong., lst Sess. (1949), which would have given the CAB international rate poviers. For a discussion of H.R. 2911, its companion bill S. 237, and earlicr, equally unsucessful efforts at giving the CAB international powers. sec Hearings on $\boldsymbol{H} . \boldsymbol{R}$. fos2, $\boldsymbol{H} . \boldsymbol{R}$. 2911, and H.R. $3940^{\circ}$ (Civil Aeronautics ACL Amendments) before a Subcomm. of the House Comm. on Interstate and Foreign Commerce, 81st Cong., Ist Sess. 21.84 (1949). 
best be appreciated by examining the powers of the $\mathrm{CAB}$ both before and after the 1972 amendment ${ }^{130}$ to the Federal Aviation Act. ${ }^{140}$ As in the Bermuda agreement itself, attention will be directed to the contrast between the Board's domestic and international powers. ${ }^{111}$

Persons undertaking to provide transportation by aircraft as a common carrier are classified as "air carriers" and "foreign air carriers" according to whether they are citizens of the United States or not.142 Air carriers may operate only by virtue of a "certificate" issued by the Civil Aeronautics Board. ${ }^{143}$ The Board must find the air carrier "fit, willing, and able to perform such transportation properly, . . . and that such transportation is required by the public convenience and necessity"; otherwise it must deny the issuance of a certificate. ${ }^{144}$ Foreign air carriers must operate under a "permit"145 which the Board may issue if it finds the carrier "fit, willing, and able properly to perform ... [foreign] air transportation" and finds that "such transportation will be in the public interest."146

While both air carriers and foreign air carriers are required to file with the Board "tariffs showing all rates, fares, and charges for air transportation between points served by it,"147 and must adhere to these tariffs, ${ }^{148}$ only air carriers providing domestic air transportation had a duty prior to the 1972 amendment, "to establish, observe, and

139. Act of March 22, 1972, Pub. L. No. 92-259, 86 Stat. 95, 1972 U.S. Code Conc. \& AD. News 806. See also pp. 1135-36, 1146 infra.

140. Pub. L. No. 85-726, 72 Stat. 731, 49 U.S.C. $\$ \S 1301$ ff. (1970).

141. For clarity, this Note contrasts the CAB's powers over "domestic" as opposed to "foreign" or "international" air transportation. More precisely, the Act divides what is here termed "domestic" air transportation into two categories. "Interstate air transpor tation" denotes transportation by aircraft as a common carrier between any two points in the United States, except for air transportation within a single state not passing through the airspace of any place outside thercof. "Overseas air transportation" refers to air transportation between the United States and any Territory or possession thercof, or between any two Territories or possessions. "Foreign air transportation" is any transpor. tation wholly or partly by aircraft between the United States and any place ouside of the United States. 49 U.S.C. $\$ \$ 1301(a)$, (b), (c) (1970). While the Board has full power to set fares to be charged for "interstate" air transportation, the Board's power over "overseas" air transportation is limited to the prescription of just and rcasonable minl. mum and maximum fares. 49 U.S.C. $\$ 1482$ (d) (1970). This curious provision, now ant chronistic, was part of the compromise in 1938 between those who wanted to give the Board equal foreign and domestic powers, those (including the airlines) who wanted the Board to have no foreign rate powers, and those who thought the Board's foreign powers should be modeled after those of the Maritime Commission. See C. RuYNE, supra notc 20, at 125-126. References in this Note to the Board's "domestic" powers are to its powers over "interstate" air transportation.

142. Unless otherwise noted, the initial section number refers to the Federal Aviation Act, Pub. L. No. 85-726, 72 Stat. 731 (1958). $\$ \S 101(3),(19), 49$ U.S.C. $\$ \S 1301(8)$, (19) (1970).

143. \$ 401(a), 49 U.S.C. \$ 1371(a) (1970).

144. $\$ 401$ (d)(1), 49 U.S.C. $\$ 1371$ (d)(1) (1970).

145. \$ 402(a), 49 U.S.C. $\$ 1372$ (a) (1970).

146. \$ 402(b), 49 U.S.C. \$ 1372(b) (1970).

147. \$ 403(a), 49 U.S.C. \& 1373(a) (1970).

148. $\S 403(b), 49$ U.S.C. $\$ 1373$ (b) (1970). 
enforce just and reasonable individual and joint rates, fares, and charges ...."149 Air carriers providing foreign air transportation and foreign air carriers were required only to refrain from subjecting "any particular person, port, locality, or description of traffic in air transportation to any unjust discrimination or any undue prejudice or disadvantage in any respect whatsoever." 150

Before the 1972 amendment, the Board's control over international tariffs was limited to ordering the removal of "unjustly discriminatory, or unduly preferential, or unduly prejudicial" tariffs. ${ }^{161}$ The Board's only influence over non-discriminatory international air fares was derived from its duty to approve or disapprove any contracts or other working agreements between an air carrier and any other air carrier, foreign air carrier, or other common carrier, including agreements for the establishment of fares. All such agreements must be filed with the Board, ${ }^{152}$ which must approve those which "it does not find to be adverse to the public interest, or in violation of [the Federal Aviation] Act."153

As amended on March 7, 1972, the Federal Aviation Act now holds all air carriers and foreign air carriers generally to the same duty "to establish, observe, and enforce just and reasonable individual and joint rates, fares, and charges ...."15t The Board is empowered to suspend for up to one year proposed or existing tariffs for foreign air transportation, and upon a finding that such fares are unjust or unreasonable or discriminatory, the Board may cancel such tariffs and prevent their use. ${ }^{155}$ Should a foreign government seek to prevent an American air carrier from charging the tariffs which the American carrier has filed with the $\mathrm{CAB}$, the Board is now empowered summarily to suspend the tariffs of the foreign government's own airline, and to order the foreign air carrier to charge the same fares as the American air carrier which

149. $\$ 404$ (a), 49 U.S.C. $\$ 1374$ (a) (1970).

150. $\$ 404(b), 49$ U.S.C. $\$ 1374(b)(1970)$.

151. $\$ 1002(f), 49$ U.S.C. $\$ 1482(f)(1970)$. This limited power to remore diserimination allowed the Board to enforce $\$ 404(\mathrm{~b}), 49$ U.S.C. $\$ 1374(\mathrm{~b})$ (1970), which enjoins air carriers and foreign air carriers from discrimination or prejudice in relation 10 "any particular person, port, locality, or description of taffic ...." Although it was never put to judicial challenge, the Board felt that $\$ 404(\mathrm{~b})$ did not permit it to regulate the general rate levels of international airlines. See Hearings of H.R. 465 , supra notc 95 , at 47 .

152. $\$ 412(a), 49$ U.S.C. $\$ 1382$ (a) (1970).

153. $\$ 412(\mathrm{~b}), 49$ U.S.C. $\$ 1382(\mathrm{~b})$ (1970). The Board's approval immunizes the carricrs party to the approved agreement from liability under the antitrust laws. $\$ 414,49$ US.C. $\$ 1384(1970)$.

154. Pub. L. No. 92-259, § 3(a), Federal Avintion Act $\S 401(a)(2), 49$ U.S.C. $\$ 1374(a)$

(2) as amended.

155. Pub. L. No. 92-259, § 3(a), Federal Aviation Act $\$ \S 1002(j)(1) \&(2), 49$ U.S.C. $\S \S 1482(\mathrm{j})(1) \&(2)$ as amended. 
flies the same route. ${ }^{156}$ The operating authority of both foreign and American air carriers is expressly conditioned upon these carriers' obedience to the Board in the exercise of its new powers. ${ }^{157}$

The Board's power to set fares is still restricted to domestic air services. After notice and hearing, the Board is empowered, upon a finding that prevailing rates are unjust or unreasonable, to fix the lawful rates to be charged for domestic air transportation. ${ }^{158}$ In determining lawful rates, the Board is directed to consider, along with such other factors as the promotion of aviation and the financial health of the carriers concerned, " $[t]$ he need in the public interest of adequate and efficient transportation of persons and property by air carriers at the lowest cost consistent with the furnishing of such service . . ."160 The Board's rate-making power is buttressed by the power to suspend for up to 180 days any new tariff proposed for domestic air transportation, while hearings are held to determine the lawfulness of the proposed tariff.100

The denial of the CAB's repeated requests that this fare-setting power be extended to cover foreign air transportation has severely handicapped the Board in seeking to promote with equal vigor the public interest in both domestic and international air services. ${ }^{101}$

156. Pub. L. No. 92-259, $§ 3(a)$, Federal Aviation Act $\S 1002(j)(3), 49$ U.S.C. $\S 1482(j)$ (3) as amended.

157. Pub. L. No. 92-259, $\$ 3(a)$, Federal Aviation Act $\$ 1002(j)(4)$, 49 U.S.C. $\$ 1482(j)$ (4) as amended. Were the Chandler fare crisis to occur today, see $\mathrm{pp} .1120 .22$ stupra, thic $\mathrm{CAB}$ could stalemate British moves to force American carriers to charge a given rate by using $\$ 1002(j)(3)$, supra note 156 , to require that British aircraft charge the fares favored by the American carriers and the $\mathrm{CAB}$. When a foreign government orders its carriers to lower its rates without forcing other airlines to comply (since the market will force them to match the lower fare anyway), as happened with SABENA in the spring of 1971, scc p. 1126 supra, the Board could act under $\$ 1002(j)(1)$, supra note 155, to stispend the new tariffs pending a hearing on its lawfulness under the duty to observe "just and reasonable" fares newly imposed upon foreign air carriers by $\$ 404(a)(2)$, supra notc 154.

158. \$ 1002(d), 49 U.S.C. \& 1482 (d) (1970).

159. \$ $1002(\mathrm{e})(2), 49$ U.S.C. $\$ 1482$ (e)(2) (1970).

160. \$ $1002(\mathrm{~g}), 49$ U.S.C. \$ $1482(\mathrm{~g})(1970)$.

161. In delegating to the $C A B$ the economic regulation of commercial aviation, Congress set forth a broad mandate to the Board for the promotion of the public interest:

In the exercise and performance of its powers and duties under this chapter, the Board shall consider the following, among other things, as being in the public interest, and in accordance with the public convenience and necessity:

(a) The encouragement and development of an air transportation system properly adapted to the present and future needs of the foreign and domestic commerce of the United States, of the Postal Service, and of the national defense;

(b) The regulataion of air transportation in such manner as to recognize and pre. serve the inherent advantages of, assure the highest degree of safety in, and foster sound economic conditions in, such transportation, and to improve the relations be. tween, and coordinate transportation by, air carriers;

(c) The promotion of adequate, cconomical, and efficient service by air carriers at reasonable charges, without unjust discriminations, undue preferences or advantages, or unfair or destructive competitive practices;

(d) Competition to the extent necessary to assure the sound devclopment of an air transportation system properly adapted to the needs of the foreign and domestic com. merce of the United States, of the Postal Service, and of the national defensc; 
While the Board has been able actively to promote the public interest in the domestic arena, making judgments as to the public benefit of given fare levels and ordering fares to be set accordingly, in protecting the public interest in the international sphere the Board's role is essentially passive. ${ }^{162}$ It can offer opinions as to the possible public detri-

(e) The promotion of safety in air commerce; and

(f) The promotion, encouragement, and development of civil aeronautics. \$ 102, 49 U.S.C. \$ 1302 (1970).

In giving the Board the power to set domestic air fares, Congress directed the Ibard to take into consideration, among other factors:

(I) The effect of such rates upon the movement of tralfic;

(2) The need in the public interest of adequate and efficient transportation of per. sons and property by air carriers at the lowest cost consistent with the furnishing of such service;

(3) Such standards respecting the character and quality of service to be rendered

by air carriers as may be prescribed by or pursuant to law;

(4) The inherent advantages of transportation by aircraft; and

(5) The need of each air carrier for revenue sufficient to enable such air carrier, under honest, economical, and efficent air carrier servicc.

§ 1002(e), 49 U.S.C. \$ 1482(e) (1970).

In exercising the suspensive powers over rates in foreign air transportation granted it by the 1972 amendment to the Federal Aviation Act, the Board has been directed to consider these same five factors, plus a sixth: "whether such rates will be predatory or tend to monopolize competition among air carriers and foreign air carricrs in forcign air trans. portation." Pub. L. No. 92-259, \$ $3($ a), Federal Aviation Act $\$ \$ 1002(j)(5)(1) \cdot(\mathrm{F})$, 49 US.C. $\$ \$ 1482(\mathrm{j})(\mathrm{F})(\mathrm{A})-(\mathrm{F})$ as amended.

162. This active-passive dichotomy in the application of the Board's public interest function begins with the initial application for authority to operate a given service on a given route. Section 401 (49 U.S.C. $\$ 1371$ (1970)) conditions the Board's issuance of a certificate to an air carrier (including one seeking opcrating authority for international service) on an affirmative finding that such service "is required by the public convenience and necessity." (Emphasis added.) See p. 1134 supra. Section 402 (49 U.S.C. \$ 1372 (1970)). on the other hand, conditions the grant of a permit to a forcign air carrier on a finding merely that the proposed service "will be in the public interest." See p. 1134 supra. This contrasting use of the terms public "necessity" and public "interest," and "required by" as opposed to "will be in," seems to impose on the Board a duty to scrutinize the applications for certificates by air carriers more rigorously than the permit applications of foreign air carriers.

The practical effect of this disparity is increased by the decision in Ashbacker Radio Corp. v. E.C.C., 326 U.S. 327 (1945), which held that two applicants for a single radio station license were each entitled to be heard before a decision was made. The fshbacker doctrine has been held applicable to $\mathrm{CAB}$ procedings for the issuance of an operating certificate for a given route under $\$ 401$. Delta Airlines v. CAB, 228 F.2d 17 (D.C. Cir. 1952). By insuring a full and scrupulous consideration of the public interests affected by the issuance of an operating certificate, the Ashbacker doctrine may well redound to the public benefit when domestic air services are involved. When international services are pending, however, an opposite result ensues. The laxer standards and diplomatic fail accomplis inherent in the granting of $\$ 402$ permits to forcign air carriers vis-d-vis the lengthy proceedings required for the issuance of a $\$ 101$ certificate allow foreign airlines to "get the jump" on American carriers in servng new markets. Thus cffective competition, declared by Congress to be one of the primary components of the public interest in air transportation, supra note 145 , is adversely affected by the contrasting statu. tory powers and administrative practices under the two sections. Cf. Hearings on $S .3197$ and $S .3198$, supra note 129 , at $16-17$.

Air carriers caught in Ashbacker's embrace in their competition for \$ 401 certificates over a new foreign air route have been unable to turn Ashbocler to their adiantage by extending its scope to include foreign air carriers. Ashbacker has been held inapplieable to a $\$ 402$ proceeding invovling a foreign air carrier who secks operating authority for $a$ route similar to that at issue in a $\$ 401$ proceeding, even though both proceedings concern petitions for operating authority over the same route. See Pan American.Crace Airways, Inc. v. CAB, 342 F.2d 905, 909 (1965), cert. denied, 380 U.S. 934 (1965); Pan Amcrican 
ment of existing fares; it can appeal to IATA for the adoption of its international fare policies. But even with the recent addition of suspensive powers over rates in foreign air transportation, the Board is unable to take the initiative in changing international fare levels. To paraphrase an IATA spokesman, the Board can still dispose of only those fares which the airlines themselves have chosen to propose. ${ }^{103}$

\section{Improving the Role of the United States in the Regulation of International Air Fares}

\section{A. Retention of the Existing Regulatory Apparatus}

In the light of the current, growing disenchantment of scholars and businessmen alike with the efficacy of transportation regulation, ${ }^{104}$ the best remedy to the United States' disadvantageous position in the existing system for regulating international air fares might seem to be complete withdrawal from that system pursuant to a unilateral policy of "deregulation." No attempt is made here to evaluate the desirability of regulation in terms of economic theory. It will be shown, however, that due to the political constraints on the international air transportation market, a unilateral American policy of deregulation would prove counterproductive to American interests.

World Airways v. CAB, 392 F.2d $483,490 \mathrm{n.9}$ (1968). For comments by a member of the CAB, see Gillilland, The Role of the Civil Aeronautics Board in Licensing Forcign Air Carriers, 32 J. AIR L. \& Com. 236, 239 (1966). Nor is the dichotomy diminished by the Board's power under $\S 416$ (49 U.S.C. $\$ 1386$ (1970)) to exempt air carricrs from the lengthy $\$ 401$ certification proceedings, for $\$ 416$ has been narrowly construcd by the courts. See, e.g., cases cited, Hearings on $S .3197$ and $S .319 S$, stupra note 129, at 2.3.

Once service is initiated on international routes, the Board's promotion of the public interest in economical air fares is still stifled by passive powers of regulation. The control over tariff agreements vested in the Board by $\S 412$ (49 U.S.C. $\$ 1382$ (1970)), sec p. 1135 supra, has proven to be of little real force or effect. First, the disapproval of an agreement requires a finding that the agreement is actually adverse to the public intet. est. Thus, the Board cannot disapprove agreements which are of limited public bencfit, even when it feels a more beneficial agreement could and should have been adopted. Second, the actual effect of disapproval under this section of the Act is minimal. As far as the Board is concerned, air carriers and foreign air carriers are free to file whattever rates they care to following disapproval of an IATA tariff agreement, and forcign gove ernments have been quick to set fares themselves if fares begin to fall during stich all "open-rate" period. See Hearings on Air Fares and Charter Service, supra note 96, at 58. An antitrust action against air carriers which continue to fly at the same rates following the Board's disapproval of a rate agreement under $\$ 412$ is theoretically possible, bitt this sanction has never been employed. See Hearings on H.R. 465, supra note 95, at 30. Finally, the suspensive power over foreign air fares given the Board by the 1972 antend. ment is still a basically passive power, since the Board cannot prescribe new rates to replace those it rejects as "unjust or unreasonable."

163. See Cohen, Crisis in the Conferences, supra note 117.

164. See, e.g., W. Jordan, supra note 119; Comment, Is Regulation Necessary? Cali. fornia Air Transportation and National Regulatory Policy, 74 YALE L.J. 1416 (1965); A Case for Grounding the CAB, FonTuNe July 1971, at 66; Editorial, Room to Mancuter, Wall St. J., Sept. 20, 1971, at 12, col. 1; The Regulators Can't Go On This Way, Bus. WEEk, February 28, 1970, at 60 . 
As the examination of the evolution of a regulatory system for international civil aviation revealed, a multiplicity of factors enter into each state's calculation of its public interest in international aviation. Among the interrelated and occasionally countervailing elements which constitute the public interest are economic, military, and diplomatic factors. ${ }^{165}$ History has shown that, because of these interests and

165. Included in the economic category are the desire of consumers for low fares, the desire of investors for a "fair return," and the need of the national economy" for a comprehensive route system and competent service. See K. l'illat, supra note 43, at 3. 32-33: $\mathrm{S}$. WHEATCROFT, supra note 82 , at $46-48$. The general value to the national cconomy of international commercial aviation prevents characterization of thesc economic factors as merely private (investor) interests versus the public (consumer) interest. Is Congressmant Kuykendall of Tennessee put it: "No matter what public grolip comes in here and talks about the public interest, it is not in the public interest to have regulated intermational and interstate transportation go broke." Hearings on Air Fares and Charer Service, supra note 96 , at 403 .

In a free enterprise economy, financial "health" for air carrien is presumed necessary to the maintenance of air services. When the government owns a direct interest in its flag carrier, as is true of most international airlines, the public stake in the balance sheet of the carrier is even clearer. Whether ownership and control of an intermational airline is private or public, the flag states involved have insariably preferred to subsidize losing carriers rather than allow them to succumb to the vicissitudes of intermational competition. See, e.g., S. WHEATCROFT, supra note 82, at 114-18, 183.85 (describing the recapitalization of BOAC by the British government following BOAC's accumulated loss of $f 80.1$ million by the end of the fiscal year 1963).

In addition to the economic factors directly related to the profitability of an airline, several subsidiary economic factors may figure in the public interest equation. Eimploy: ment levels in the airline industry, and in the airframe manufacturing industry as well, must be considered. See, e.g., F. ThaYer, supra note 22, at 184-85. Employment will be related to other considerations besides providing jobs for a statc's citizens; as a source of skills and technological capability, aeronautical industries may be maintained eves when they are uneconomic. See R. ThorNTox, supra note 31, at 101-05. The British have been the most notorious nation for sacrificing the economic well-being of their carricrs, and their ability to operate on Iower fares, so as to support the national airframe manufacturing industry. See R. WORCESTER, Roots of BritisI AIR PouIC: 1G1.78 (1960); CoMM.

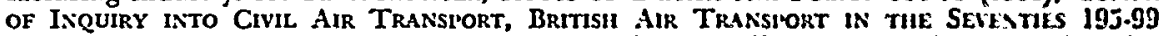
(1969); M. StraszheIM, supra note 72, at 23. Britain's belligerence during the Chandler fare crisis can be attributed to BOAC's chronic need for higher fares to offset the losses it incurred in purchasing prematurely obsolete British equipment instead of Americanmade long-haul jets. Cf. S. WheATCROFT, supra. The problem seems likely to arise again should BOAC and Air France be ordered by their respective governments to purchase the Concorde SST irrespective of its commercial viability.

The military factor is a further aspect of the national interest in financially "healthy" carriers. Military planners see well-staffed and equipped civil airlines as a transport reserve. See generally F. THAYER, supra note 22, passim. Defense strategists will accordingly support policies which maximize the number of civilian transpore aircraft and their availability to the military. In balancing the value of such policies against the cost, the military may well discount costs which are paid out of commercial reienues or consumer pockets instead of the national defense budget.

Both economic and military factors may merge into the diplomatic categon: National airlines are vehicles of prestige and propaganda, carrying on the maritime tradition of "showing the flag." 0 . LissirzYs, supra note 1, at 56.57. International airlines may be not only major foreign exchange earners in their own right, see W'. O'Cossos, supra note 31, at 94; R. THORNTON, supra, at 92-101, but may also stimulate the development of trade with countries they serve. M. Struszheik, supra, at 9-16. Moreover, international airlines function as foreign policy poker chips. Concessions on routes or fares may be traded off for advantages gained in other spheres of forcign affairs.

American acquiescence in high fares and the award to many forcign-flag carriers of lucrative routes to and from American cities has been a covert form of financial aid to co-operative allies, free from the recurring revicw to which congressionally appropriated aid is subject. Such "foreign aid" has been used to secure American military bases on for- 
the correspondingly high value nations place on airline ownership and operation, governments will not allow their airlines to live or die at the mercy of market forces. ${ }^{160}$

The Chicago Conference, ${ }^{167}$ the Chandler fare crisis, ${ }^{168}$ and the European subsidy battles of the 1920 's and $1930^{\prime} \mathrm{s}^{160}$ exemplify threc strategies available to protectionist countries for the frustration of an American deregulation offensive. The first strategy, the sort displayed at Chicago, is a boycott of air service with the United States by a group of contiguous countries. The "Third World" of today can, like wartorn Europe a quarter-century ago, successfully condition access to its airspace on protection for its airlines. The artificially high fares necessary on routes to underdeveloped countries for the economic survival of these countries' airlines may be the "price" charged for inclusion of these nations within a global route network. The United States should rationally agree to pay this price, through the acceptance of rate regulation, so long as the cost in the form of inflated fares does not exceed the benefit of the resultant air service.

The United States interest in deregulation stems primarily from an ability as a wealthy, technologically-advanced nation to support the efficient airlines necessary for successful competition in a free air transportation market. But also a function of wealth and industrialization are the indirect benefits, aside from those values accruing directly from airline operation and ownership, of participation in a comprehensive network of global air service. These indirect benefits, realized in terms of expedited trade and communications, flow disproportionately to prosperous countries like the United States. Thus the loss of these indirect benefits would inflict greater damage on the United States than it would on the underdeveloped countries which might boycott air service should the United States seek to deregulate international rates.

The absolute cost of such a boycott would thus be greatest for the United States. The relative cost might be higher for the boycotting countries, however, because they have fewer resources with which to

eign soil. A classic instance of using air routes to keep a NATO ally smiling was the award of routes to New York and Houston to the Dutch national carrier KLM in 1057. Sec $\mathrm{F}$. THAYER, supra, at 78-79; R. THORNTON, supra at 99. See also Hearings on $S .1539$ and $s$. 1540, supra note 78, at 24; Edles, IATA, The Bilaterals, and International Aviation Policy, 27 FED. BAR J. 291, 298 (1967). Strategic considerations have not caused a "tilt" solely in thic favor of IATA countries. The value of American air bases in Iceland las been crcdited with deterring the State Department from renegotiating the United States bilateral air serv. ice agreement with Iceland, which permits Icelandic Airlines to serve the United States and Europe at sub-IATA rates. M. STRASZHEIM, supra at 54.55; cf. note 105, supra.

166. See, e.g., pp. 1106, 1107, 1114 supra.

167. See pp. 1110.13 supra.

168. See pp. 1120-22 supra.

169. See p. 1106 supra. 
absorb the costs which a boycott would generate. Although this circumstance might make a battle by attrition against a boycott seem economically rational for the United States, political factors must also be taken into account. Politicization, within both the boycotting countries and the world arena, could artificially prolong the boycott. The governments of the boycotting countries might find it politically impossible to capitulate and stay in power; given that the United States would have provoked the boycott by withdrawing from IATA in pursuit of deregulation, rival great powers would probably appear with offers to subsidize the cost of the boycott.170 Thus the United States might find itself faced with rising barriers to re-entry into the boycotting countries even if it capitulated to those countries' claims for the regulation of air fares. ${ }^{171}$

A second caveat to the economic wisdom of the United States' seeking to prevail against such a boycott is posed by the contradiction between the effects of such a policy and the supposed purpose of foreign aid programs. Foreign aid seeks to foster economic growth in the developing world by compensating for and seeking the elimination of some of the underdeveloped countries' disadvantages in the world trade market. ${ }^{172}$ The admission implicit in foreign aid is that this market's allocation of resources, however efficient, is inequitable. It might well lend the appearance of bad faith, if not inconsistency, to American foreign aid if the United States were to undertake a program of aiding

170. Such a subisidy could take two forms. Direct pajments in cash, goods, and services could seek to redress the harm inflicted on the bojcotting countrics ceonomics. Mlore likely, however, would be the provision of alternate air service, linking the boycotting countries to a route network radiating from the friendly power. The underdeveloped countries' participation in this alternate air service would be subsidized by the intervening power, seeking to establish its own sphere of aeronautical influence. Cf. $R$. ThORNToN, supra note 31, at $152-53$ (describing a Soviet attempt to achictc acronautical pre-eminence among new African nations).

171. Should the United States withdraw from IATA, thereby provoling a bojeott of the type hypothesized here, most American bilateral air service agreements would have to be renegotiated. The Bermuda-type bilateral is predicated on IATA's priman ratesetting competence, see pp. 1115-16 supra, and it would hardly be honorable for the United States to decide to begin disapproving all IATA tariff agrecments without announcing this change of policy in advance and giving the stipulated one jear's notice for denunciation of its Bermuda-type bilaterals. See, e.g., Air Services Agreement with the United Fingdom, Feb. 11, 1946, art. 13, 60 Stat. 1503, T.I.AS. 1507 ["Chicago form," $c$. note 58, supra]; Air Transport Agreement with the Fed. Rep. of Germany, July 7, 1955, art. 16 [1956] 1 U.S.T. 540, T.I.A.S. 3536 ["Bermuda form," cf. note 58 supra].

It would thus be quite difficult to "call off" an unsuccessful deregulation initiative. By contrast, when Britain threatened to end American landing rights during the Chandler Fare Crisis, she was acting within her rights under the Bermuda bilateral agreement. But see note 210 infra. When her grievance was satisfied, she could return to the status quo ante. American efforts to achieve the United States air fare goals outside of the IATA framework would be based on economic power and sovercign prerogatives, not negotiated rights, and there would thus be no guarantee that a restoration of air service could be had solely at the United States' initiative.

172. See, e.g., C. Kindleberger, EcoNomic Developareir $361-79$ (2d ed. 1965). 
economic development in a country while simultaneously attacking one of its efforts at industrialization, its national airline. ${ }^{173}$

Current attacks on IATA are often premised, however, on the modern equivalency of European and American industrial power. ${ }^{174}$ While the boycott strategy would be inappropriate, Europe could respond to American withdrawal from IATA with the same strategy employed during the Chandler fare crisis. Acting multilaterally, the European governments could write into their municipal law the tariffs which would have been incorporated in an IATA tariff agreement. ${ }^{175}$ For the United States to respond to this by itself setting fares for its Third and Fourth Freedom traffic with Europe would be an admission of defeat in its effort at deregulation. ${ }^{170}$ When multiple sovereigns con-

173. Although creation of a national airline may not be an optional usc of cconomic resources, national airlines have a psychological value which cannot lightly be dismissed. See W. O'Connor, supra note 31, at 96. Arguments that the use of higher fares to sub. sidize airline ownership and operation by modernizing nations is an inefficient allocation of foreign aid resources may fail to take this non-quantifiable factor sufficiently into ac. count. Cf. K. PILLAI, supra note 43 , at $17-18$. Second, the spillover benefits of airline operation into other sectors of the economy are also difficult to calculate but arc never. theless significant. See note 165, supra. Third, it may be unwise to end air farc "forcign aid" without any assurances that the same amount of aid will be channelled into other sectors of the economies of underdeveloped countries. A final consideration is whether a paternalistic attitude toward underdeveloped countries which insist on entering the international airline business is prudent, even if warranted by the fact that such invest. ments may be an inefficient allocation of the countries' resources. Years of "dollar diplo* macy" may have engendered suspicion of American economic advice.

174. Given the wealth of modern Europe, disruption of air service in retaliation for American withdrawal from IATA is therefore unlikely to be instigated by the Euro. peans, for it would inflict no disproportionate injury on the United States vis-di-vis Europe. Moreover, the relaxation of Cold War tensions and the gradual realignment of super-power politics into a tripartite contest for Third World sympathies have reduced the need for American economic concessions to Europe in return for NATO support. $\Lambda$ dispute over airline fares with a European government seems unlikely to push such it state to the brink of revolution. Indeed, it has been suggested that, in view of the flow of wealth accompanying the yearly horde of American tourists abroad, the Unitcd States should consider employing the boycott strategy itself to induce compliance with $A$ incti. can deregulatory demands. See K. PiLlai, supra note 43, at 142-143.

175. This strategy is also available to some non-European countries too wealthy to have a bargaining advantage in a boycott. Japan, for instance, has long sought to malti* tain high fares on transpacific routes. Cf. note 123, supra. Because of Japan's island geography, Japan needs no multilateral "Fifth Freedom" protection. Thus Japan has been able to achieve its fare policies by simply setting fares under its own law whencver the CAB disapproves a transpacific IATA rate agreement. Following CAB disapproval of IATA's transpacific rates in 1963, an "open-rate" situation prevailed for four years, during which American carriers continued to fly at the 1963 rates. See $1967 \mathrm{CAB} \Lambda \mathrm{NN}$. REP. 35; 1968 CAB ANN. REP. 50-51. An "open-rate" situation again arose in 1969, and again no reductions in fares occurred. See 1969 CAB ANN. REP. 25.

176. In order to set rates on its Third and Fourth Freedom traffic, Congress would have to grant the $\mathrm{CAB}$ the international rate powers advocated by this Note. Having finally armed itself with international rate-powers, it would be extremely foolish for the Unitcd States to then denounce its bilateral agreements, $c f$. note 171, supra, and withdraw from IATA, at the very moment when provisions in our bilaterals conducive to lower fares have at last become effective. See p. 1150 infra. In any case, the United States would be at a disadvantage in a rate-setting contest with Europe, absent accord with Canadat and Mexico, because we would not have the collateral "Fifth Frecdom" protection which the Europeans have in the past secured through their unanimity in confrontations with the United States. See pp. I129-30 supra. 
trol access to the marketplace, one state's attempting to legislate a "free" market is futile. The resulting mass of ad hoc legislation would burden air transport in as costly a fashion as IATA's price-fixing, without IATA's offsetting advantages of a low political profile and integrated tariffs.

A third strategy for sabotaging an American attempt at deregulation would follow the pattern of the European subsidy battle between the First and Second World Wars. Even when used merely to underwrite inefficiencies and thereby to preserve a carrier's "competitive position," subsidies distort the market. ${ }^{177}$ The intra-European subsidy battles of the inter-war years offer historical evidence that subsidies can be used as predatory as well as compensatory devices. In the current context of privately-owned American carriers, it would be a relatively simple and short-term matter for a single state to start a subsidy battle through the introduction of below-cost fares, and then await the collapse of the American carriers. The United States could and probably would join the subsidy battle to support American carriers, but this would lead to the inequity of all American taxpayers subsidizing a lowfare bonanza for the minority of Americans who would actually travel abroad. Because all states would have to join the battle or lose their airlines, the cumulative cost of a subsidy battle may be greater than the costs generated by regulation.

The availability of these strategies for frustrating a unilateral American policy of deregulation places regulation in its proper perspective as a political necessity. Regulation of air fares functions as a means of "buying" access to much of the international commercial aviation market. As long as the present system of sovereign political jurisdictions remains the central feature of international law, many air transport markets will be open only to non-price competition.

Accepting the need for regulation presents the question of the form which the regulatory process should assume. Some commentators have proposed a system of direct intergovernmental negotiation of air fares. ${ }^{178}$ This Note has sought to demonstrate that much of the bar-

177. When subsidized airlines keep flying instead of going bankrupt, they create excess capacity. The passengers who fly on these carriers vould, were the market allowed to prevail, have to fly on the unstbsidized carriers efficient enough to survive in a competitive market. This would raise the load factors of the unsubsidized airlines, lowering their average costs and allowing them to offer lower rates. Consequently, even where subsidies are paid merely to allow an airline to stay in the market and offer air transport at the "market price," this price, as set by the most cfficient carriers, is still inflated due to the inefficiency imposed upon the whole system by the continued operation of the subsidized carriers.

178. Id. at 122-36; W. O'ConNor, supra note 31, at I3I ff. See also Statement of Dr. K. Pillai, Hearings on S. 2423, supra note 102, at 230-31. Professor Thajer advocates re- 
gaining within IATA is in fact intergovernmental. Insofar as political considerations dominate the economics of IATA, transferring IATA's regulatory role to an officially diplomatic organization would promise little improvement in IATA pricing policies. A far more likely result of such a mechanism would be the aggressive assertion of sovereignty into a delicate bargaining process. ${ }^{179}$ This Note therefore advocates exploiting the advantages of IATA, and minimizing its abuse of the American public interest in lower air fares, through a more potent means of representing American interests within IATA.

\section{B. Alternative Means of Enhancing American Influence within IATA}

A campaign to enhance American influence within IATA must proceed along two fronts. First, some assurance must be gained that claims for the protection of the American public interest will be articulated within IATA, and second, provision must be made for the political sanctions necessary to insure that such claims are effectuated in the face of resistance from other IATA members.

The articulation of the American public interest could perhaps be

organization of American-flag international airlines into three regional, quasi-public inter. national airlines, each being the sole United States flag airline in its area of operation. See F. Thayer, supra note 22, at 304-06; Thayer, Air Transport Policy: $A$ Crisis in Theory and Practice, $36 \mathrm{~J}$. AIR L. \& CoM. 661 (1970). Professor Thornton urges a tougher bargaining posture for United States air route negotiations, but within tlic existing IATA rate-setting structure. Foreign support for American goals within IA would be one of the concessions sought through tighter controls on access to the luctat. tive American air travel market. See R. ThorNron, supra note 31, at 241.42; Thornton, Power to Spare: A Shift in the International Airline Equation, 36 J. Ank L. \& Con. 673 (1970). Dr. Straszheim likewise advocates better United States bargaining within the IATA framework, but specifically rejects vesting the $\mathrm{C} \Lambda \mathrm{B}$ with international rate. setting powers. See M. SrRaszuerM, supra note 72, at 206.20.

179. While IATA fare-setting is rife with political factors, international air transpor tation as a service and a livelihood for millions has remained remarkably frec of cutall. glements with the day-to-day strife of modern "public" politics. Intrusions of political hostilities into the airline industry, such as the hijackings of airliners by $\Delta$ rab guctillas, provoke a nearly universal chorus of denunciation. Except during outright war, airlinc's pass daily between states separated by bitter political disputes, providing a welcome te. source of communication and a vivid illustration of the possibilities of peaceful coexist. ence. Thus while sovereign claims to territorial airspace are implicit within the whole air transport system, under prevailing conditions these claims are not rattled along with the other sabres in the sovereign closet. While airlines and air routes are the subject of intensive, long-term bargaining, they are not commonly uscd as means for short-term sanctions or reprisals.

Air fares are, however, negotiated and renegotiated much more frequently than air routes, and are much more interdependent. The publicity surrounding these recurrent negotiations would not be conducive to the understatement of sovercign claims to control of the national air. Fare policies articulated in an inter-governmental confercuce, once widely publicized, might be backed up with threats of exclusion from national alispace of those who disagreed. Dependable air service over a global route network could easily be eroded by the ebb and flow of political influence and alliances. These dangers can be avoided by preserving the airline-to-airline facade of the existing rate regulatory process, while nevertheless securing better representataion for American interests in the covert political process which underlies the otherwise commercial atmosphere of fare negotiat. tions. 
most forcefully achieved through the nationalization of the United States' flag airlines. American representation within IATA would thus become a governmental function, with consequent political responsibility. Adequate alternatives exist, however, which serve the goal of protecting American interests from abuse by IATA without confusing the issue of reforming IATA with the more complex problem of the advisability of national ownership of major industries.

These alternatives involve legislation granting the $\mathrm{CAB}$ sufficient regulatory authority over international aviation to allow the Board to utilize effectively the provisions of the Bermuda-type bilateral air service agreement. ${ }^{180}$

The principal problem with the Bermuda-IATA system from an American perspective has been Congress' failure for twenty-six years to pass the legislation necessary for the United States to take advantage, consistent with its own municipal law, of the Bermuda bilateral's reservation of sovereign rights of action under international law. Thus when the $\mathrm{CAB}$ has in fact disapproved an IATA agreement, it has found itself unable "to prevent the inauguration or continuation of the service in question at the rate complained of," 181 as allowed by paragraph (f).182 Implementation of paragraph ( $f$ ) by suspending the operating rights of foreign air carriers required specific statutory delegation of such "paragraph (f) powers" from the Congress to the CAB. This delegation was not effected until March 22, 1972.183

Throughout the years when it was unable to take advantage of paragraph $(f)$, the $C A B$ campaigned for the powers which would activate paragraph (e) of the Bermuda bilateral. These powers "to fix fair and economic rates for the transport of persons and property by air on international services and to suspend proposed rates in a manner comparable to that in which the Civil Aeronautics Board at present is empowered to act with respect to such rates for the transport of persons and property by air within the United States," 181 would bring paragraph (e) into effect in place of paragraph $(f)$ for all signatories of Bermuda-type bilaterals. This would allow the $C A B$ to prescribe the proper rates for American international airlines while simultaneously creating a binding obligation upon other governments to allow these airlines to serve their countries at the CAB-set rates. But because the

180. See pp. 1115-17 supra.

181. Annex, § II, paragraph (f), Bermuda bilateral, supra note 55 . See note 62 supra.

182. See $\mathrm{p}$. 1118 and note 162 supra.

183. Act of March 22, 1972, Pub. L. No. 92-259, 80 Stat. 9J, 1972 U.S. Code CoNic. \& AD. News 806.

184. Annex, $\S$ II, paragraph (e), Bermuda bilateral, supra note 55 . See note 63 supra. 
$\mathrm{CAB}$ has not had the powers which would invoke paragraph (e), other states have remained free to fix international air fares themselves and to reject fares they disapprove of, with the sovereign abandon permitted under paragraph (f). ${ }^{185}$ Unlike paragraph (e), which allows a state to set rates only for its own airlines, the continued regime of parigraph (f) has allowed foreign governments to prescribe the legal fares American airlines must charge on international flights to and from the United States. The CAB's prolonged lack of the "paragraph $(f)$ powers" necessary to retaliate in kind against such rate-setting by foreign governments has rendered it impotent in past international fare disputes.

As concern over the possibility of a rate war on the North Atlantic route mounted during the summer and fall of 1971, the CAB sent to the Congress a draft bill presenting the Board's view of the powers it required to protect the public interest in international aviation. Introduced in the Senate as S. 2423, ${ }^{186}$ hearings on the bill were held on October 19-21, 1971.187 During these hearings spokesmen for the Administration supported the American scheduled airlines in their advocacy of an alternative draft bill. The substance of the Administrition-industry proposal was substituted for the language of the $\mathrm{CAB}$ version in the amended draft of S. 2423 which was reported out of com. mittee in January ${ }^{188}$ and passed by the Senate on February 24, 1972.180 Immediately after the Senate hearings in October, a companion bill to S. 2423 was introduced in the House. ${ }^{190}$ The House passed this bill on March 1, 1972,191 and proceeded to amend and pass the Senate bill so that it conformed exactly to the House version. ${ }^{102}$ S. 2423 as amended by the House was then passed by the Senate on March 7, 1972,10a and signed into law as Pub. L. No. 92-259 by President Nixon on March 22, 1972.194

185. See Hearings on S. 2423, supra note 102 , at $37-39$.

186. S. 2423, 92d Cong., 1st Sess. (Aug. 4, 1971).

187. Hearings on $S .2423$, supra note 102 . The author of this Note attended the hear. ings and appeared as a witness on October 20, 1971. Portions of this Note were incorpo. rated in the author's prepared statement to the Subcommittec, id. at 101.08.

188. S. Rep. No. 92-593, 92d Cong., 2d Sess. (Jan. 24, 1972).

189. 118 Cong. REC. S2457 (daily ed. Feb. 24, 1972).

190. H.R. 11416, 92d Cong., 1st Sess., (Oct. 21, 1971). Having been amended in com. mittee so as to contain language virtually identical to that of $\mathrm{S}$. 2423 as passed by the Senate, the House bill was reported out of committee on the same day that S. 2423 passed the Senate. H. Rep. No. 92-854, 92d Cong., $2 d$ Scss. (Feb. 24, 1972).

191. 118 ConG. Rec. H1636 (daily ed. March 1, 1972).

192. Id. The differences between H.R. 11416 as passed by the House and S. 2129 as passed by the Senate were the presence in the House bill of $\S 3(\mathrm{~b})$, amending the table of contents of the Federal Aviation Act to conform to the amended powers of the $\mathrm{CAB}$, and the presence in the Senate bill of a $\$ 5$ providing that the bill would take cffect upon enactment.

193. 118 Cong REc. S3467 (daily ed. March 7, 1972).

194. 118 Cong REc. D314 (daily ed. March 24, 1972). 
The CAB draft of S. 2423 was a "paragraph (e)" bill. ${ }^{105}$ By giving the $\mathrm{CAB}$ the same authority to set and suspend rates in foreign air transportation that it currently has for domestic air transportation, it would at last have made operative paragraph (e) of the Bermuda bilaterals. Spokesmen for the White House and for the American carriers strongly opposed the $C A B$ draft precisely for this reason. By vesting the $C A B$ under municipal law with plenary rate-making powers over international aviation and thereby invoking paragraph (e), the CAB draft would have denied to the United States under international law the right to prevent new fares from being put into effect by foreign carriers. Uppermost in the minds, and the testimony, of the opponents of the CAB draft were Lufthansa's threats to bolt IATA and initiate a North Atlantic rate war. Those opposing the CAB draft simply wanted Congress to allocate authority for retaliation against what was widely seen as a predatory price policy. ${ }^{106}$ The amended draft of S. 2423 which was enacted into law followed this recommendation. The legislation was confined to a grant of paragraph $(f)$ powers. ${ }^{107}$

195. CAB orders affecting international rates were to be reported to the President, but were not made subject to his approval. In its provision for international rate powers and its excision of Executive review, the CAB draft was similar to S. 1510 of the 88th Congress, as passed by the Senate. See notes 90 and 95 , supra. The C.1B draft of S. 2423 contained a novel provision, however. Section 6 would have allowed the Board "in its discretion and without a hearing" to suspend for up to one jear the tariffs of a forcign air carrier and to force such foreign air carrier to change the same rates as charged by American air carriers for the same route. Foreign air carrier adherence to such orders of the Board would be a condition of continued operating authority for such foreign air carriers to serve the United States. This provision for summary action by the Board would not have impinged on paragraph (e), because the draft specifically stated in $\$ 8$ that nothing in the bill should be deemed inconsistent with \$ 1102 of the Federal Aviation Act, 49 U.S.C. $\$ 1502$ (1970), which directs the Board to carry out its duties consistcnt with any international obligations assumed by the United States. The new "Iallback" powers would have insured protection of the United States' public interest should another country renounce or ignore its air service agreement with the United States. In such a crisis, the Board could take immediate action against such country's air carriers without having to wade through the administrative procedures and cndure the inevitable delays in order to revake a foreign air carrier permit under $\$ 402$ of the Federal Aviation Act, 49 U.S.C. $\$ 1372(1970)$. Cf. note 93 supra.

196. See, e.g., Statement of Bertram Rein, Dep. Ass't. Sec., Dep't. of Statc, Hearings on S. 2423, supra note 102, at 35, 40; Statement of Stuart Tipton, President of the Air Transport Association, id. at 200.

197. The Air Transport Association (ATA), the trade association of the scheduled American airlines, advanced a dusted-off copy of the bill which they had submitted to the 88th Congress as a rival to the Whie House's S. 1510 . See Statement of Stuart Tipton, President of ATA, Oct. 21, 1971 (mimeo. copy distributed at the Hearings on S. 2403 on file at the Yale Law Journal); cf. S. 1539, 88th Cong., 1st Sess. (1963). This ATA draft provided for the suspension of any proposed or existing tariffs of foreign or American air carriers which the Board found contrary to the public interest. $A$ list of public interest factors included in the proposal vould have limited the Board's suspension power to unjust or unreasonable tariffs, as determined according to the chameteristics of the service in question. The length of suspension was limited to one year, and the fares to be charged by carriers whose tarifts were suspended vere to be lie fares in effect prior to the suspended fares.

The Administration did not present its own draft at the Senate hearings, although it promised to do so later. Statement of Charles Baker, Ass't. Sec. Dep't. of Transportation, 
Public Law No. 92-259, in this emphasis on the recent phenomenon of a threatened rate war, ignores the historical problem of IATA's reluctance to heed American requests for lower basic fares. Just two days before Lufthansa's ephemeral fares were denounced by ashen-

Hearings on $S .2423$, supra note 102, at 119. The Department of Transportation's bill wals introduced in the House on Nov. 16, 1971, as H.R. 11825, 92d Cong., Ist Sess. (1971). St'C H.R. REr. No. 92-854, 92d Cong., 2d Sess. 15-16 (1972). The Administration proposal sought to achieve the same ends as the ATA proposal, albeit through somewhit more elaborate language.

The amended draft of $S .2423$ reported out of the Aviation Subcommittec to the full Committee on Commerce followed the Administration and industry recommendations that legislation be confined to paragraph (f) powers. S. 2423, 92d Cong., 1st Sess., Comm. Print (Nov. 17, 1971). The Subcommittee draft contained several refinements of the $\Lambda^{*} \Lambda$ draft, however. The ATA has maintained since 1963 that no further legislation was necessary to establish the authority of the Board to act under \$ 102 of the Federal Aviation Act, 49 U.S.C. $\$ 1372$ (1970), to revoke the operating rights of foreign alle cat* riers whose governments have acted prejudicially to American carriers. This broad tead. ing of $\$ 402$ is probably incorrect. See note 93 supra. Thus, Section 3 of the Subcoul. mittee draft provided that Board orders affecting rates must be obeycd by air curricts and foreign air carriers as a condition to their continued rights to operate in the United States. The Subcommittee draft also avoided the problem of litigation over administrative procedures during a crisis by retaining the "fallback" powers of stummary action pro. posed by the $\mathrm{CAB}$ (in addition to paragraph (c) powers) in its draft of S. 2423. Morcover, the Subcommittee expanded somewhat the suspensive powers proposed by the $\Lambda^{*}{ }^{\prime} \Lambda^{\prime}$. While the ATA would have limited the CAB to the power to suspend unjust or uil. reasonable fares for up to one year, the Subcommittec draft provided for a onc year suspension during which the Board might, after hearing, order the cancellation of the suspended fare. The grounds for suspension under the Subcommittec bill are the ill. justness or unreasonableness of the fare. The Subcommittee language in this regard was somewhat stricter than the ATA's. The ATA draft predicated suspension on the Board's determination that the suspended fare was "inconsistent with the public interest." This connotes the "passive public interest" test under existing $\$ 412$ of the Federal Aviation Act, 49 U.S.C. $\$ 1382(1970)$, see pp. 1135, 1136-38 supra. By contrast, the Subcoll. mittee bill placed an affirmative duty on air carriers and foreign air carriers to cstablish just and reasonable fares, and made suspension of a fare a preliminary to an inguiry is to its lawfulness. The language and procedure of the Subcommittec draft thus made the suspensory process regarding fares in foreign air transportation substantially the sanc as that for fares in domestic air transportation, with the exception that the Board hats no power to prescribe the lawful fare in forcign air transportation. In short, the stibcoul. mittee draft seemed to allow the Board to scrutinize international fares much more closely than would the ATA draft with its vaguer "public interest" mandate, Fintlly, the CAB draft provided for no Executive review. Although ostensibly this omission was because CAB fare orders are "technical" matters with which the president need not bo bothered, it in fact represented the pique of the Board and Congress with, first, presi. dential "softness" during the Chandler fare crisis, and second, the political wrangling during successive administrations concerning the award of new transpacific routes. Sce Hearings on S. 2423, supra, at 27; cf. p. 1123 supra. 'The Administration objected strent1. ously to any bill which failed to provide for Executive approval of $C A B$ rate actions. Hearings on S. 2423 , supra note 96 , at 35,110 . The Subcommittee responded to the president's claims of constitutional power to review $C A B$ rate orders with an innovative pro. vision reflecting congressional distrust of past usage of executive review in aviation matt. ters. Section 2 of the subcommittee draft sought to forclose constitutional objection by making $\mathrm{CAB}$ orders suspending or rejecting rates subject to the President's disafprot'il. A Presidential decision to disapprove a $\mathrm{CAB}$ order would have had to have been anl. nounced within ten days of the Board's submission of the order to the White House, and to have been accompanied by a written statement "explaining in detail the reason or reasons for disapproval." Cf. Hearings on $S .2423$, at 99.

The full Senate Committee on Commerce, in reporting S. 2423 to the floor, S. REr. No. 92-593 (Jan. 24, 1972), made only one significant change in the Subcommittec draft. Execu. tive review was limited to ten days' right of disapproval, but no written explanation of such disapproval was required. The president was, however, required to find "that dis. approval is required for reasons of the national defense or the forcign policy of the United States ...." This language was retained in the version which became law. 
faced airline presidents appearing before the Senate Commerce Subcommittee which held hearings on $S .2423,{ }^{108}$ the chairman of the CAB had emphasized to the subcommittee that the Board's long-term problem remains obtaining lower fares from IATA.100 The paragraph (f) powers which are now law do not meet this problem for two reasons.

First, paragraph (f) was framed to protect the status quo. Its sanctions are available only against new rates. As long as the sanctions authorized by paragraph (f) are not exceeded, a fare dispute will lead to stalemate, with fares maintained at existing levels. This is no accident. In 1946 the British feared Pan American World Airways much more than they did the United States government, which might be trusted to have some concern for a faithful ally. ${ }^{200}$ The raison d'elre for the alternative paragraphs (e) and (f) was to allow the British to maintain their postwar high fares until such time as the $\mathrm{CAB}$, rather than Pan American, would be setting the rates for American carriers. Thus, while paragraph $(f)$ powers for the $\mathrm{CAB}$ will afford some protection to the American public interest in aberrant situations where the $\mathrm{CAB}$ is seeking merely to retain the existing fare structure against proposals for a fare hike, paragraph ( $f$ ) is useless to the United States in its usual efforts to lower fares.

In contrast, paragraph (e) obligates the parties to Bermuda-type bilaterals to allow proposed fares to go into effect pending arbitration. ${ }^{201}$ Given the high comparability of air transport services, such that any significant difference in price will create a substantial diversion of traffic, ${ }^{202}$ paragraph (e) has a built-in bias toward lower fares. A party proposing a new, higher fare poses no threat to a party which does not see the need for a price increase; on the other hand, a party proposing

198. Hearings on $S .2\{23$, supra note 102 , at $212,239-40$.

199. Id. at 27.

200. See p. 1117 supra.

201. See note 63 supra.

202. As between airlines flying similar equipment between the same cities, the comparability of the service offered is total save for differences in scheduling, in-flight amenities, ethnic appeal, and the chances for a safe arrival. Times of departure are not subject to any current controls, and so many flights tend to be scheduled at the same time. The experience with the introduction of tourist class in 1952 and economy class in 1958 shows that the air transport consumer's preference for lower price is strong enough to overcome even significant differences in comfort and service during the flight. Sec p. 1120 supra; M. STRASZHEIM, supra note 72, at 119-20. Ethnic appeal has proven to be a strong competitive force for choosing between equal-fare airlines, but it is doubtful that this refinement of service competition could stem the diversion induced by price competition. Relative safety records might influence the expert's choice of airlines, but the average consumer has little access to the pertinent statistics, and the airlines themselses refuce to capitalize on each other's tragedies because of the spillover effect of each individual airline's mishaps on the reputation of the air transport industry as a whole. For a revies: of the more limited diversion of traffic which price competition an achicve when routes and equipment are not totally comparable, see note 105 supra. 
a lower fare will force the other party to match its price pending arbitration. ${ }^{203}$

This low fare bias under paragraph (e) would create an incentive for high fare airlines to cope with low fare initiatives within IATA rather than risk a temporary open-rate situation. Under paragraph ( $f$ ), however, a single airline might not hesitate to veto an IATA agreement contemplating lower fares, for that airline's flag state knows that it can, in the absence of a mutually acceptable IATA tariff, prevent the inauguration of service at the lower rate, at least on routes serving the objecting state. Moreover, this advantage to high fare advocates is magnified when such countries act in geographically contiguous concert. ${ }^{204}$ Under paragraph (e), however, the leverage would be reversed. If agreement within IATA were sabotaged or an IATA agreement were governmentally disapproved, high fare states would have no further lawful means to prevent lower fares from taking effect short of general diplomatic pressure. Their wisest course of action would be to salvage what concessions they could within IATA. ${ }^{205}$

Second, paragraph (f) powers not only inhibit the effectuation of American low fare policies, but they leave even their articulation within IATA to the whim of American carriers. American carriers satisfied with a high fare status quo are immune from $\mathrm{CAB}$ sanctions because of the purely suspensive nature of paragraph $(f)$ powers. Since prescriptive rate powers are denied to the $\mathrm{CAB}$, there is no way of insuring that American carriers will press for lower fares within IATA. ${ }^{200}$

203. The low-fare bias of paragraph (e) exists notwithstanding the provision for arbitration. Much of the disagreement between the $\mathrm{CAB}$ and foreign governments may ba traced to differing expectations about the effect of reduced fares on carriers nct revenues. See note 128 supra. Paragraph (e), by allowing lower rates to remain in effect pend. ing arbitration, would permit empirical study of the effect of lower rates. This data would either win support for the CAB's economic theories or force the Board to re. examine the assumptions underlying its "low-fare philosophy." Morcover, the arbitrit. tion proceedings could well prove quite lengthy. The prospect of the CAB setting lower fares for American carriers, and paragraph (e)'s guarantee of their effectiveness throughout a lengthy period of arbitration, maintains the potency of paragraph (c) in its prin. cipal role of increasing the incentives for intra-IATA agreement on lower farcs.

204. See p. 1130 supra.

205. The restraints of paragraph (e) are basically self-imposed, however, and there is always the danger that a petulant state may simply disavow its obligations under a bl. lateral agreement. Or, a state might simply terminate its bilateral agreements on onc year's notice. See note 171 supra. Since some regulation of air fares is necessary, it is incumbent upon countries desiring generally lower fares to "bargain in good faith," and not to seek to establish indirectly a "free enterprise" price of air travel by lowering air fares until only the most efficient and well-capitalized carriers can afford to operate. Paragraph (e) should thus be used to encourage negotiated reductions under the acgis of IATA, rather than to force reductions down the throats of recalcitrant countries on the theory that the literal language of paragraph (e) will restrain such countries from tak. ing reprisals.

206. A difficult question of construction would arise if the Congress were to grant the $\mathrm{CAB}$ power to fix rates for foreign air transportation for American carriers only. 
In contrast, invoking paragraph (e) by authorizing the CAB to set international rates would enable the Board to moderate the intraIATA behavior of American carriers. ${ }^{207}$ As the United States seeks a suitable stasis between coercion and concession, there is a constant danger that the public interest may diverge from the interests of the American international carriers. A certain amount of discretion is the price of using the IATA forum, with its attendant benefits of nominally apolitical regulation and overtly voluntary compliance. But too large a measure of discretion cannot be accepted. If the CAB were armed with paragraph (e) powers, the Board's suggestions of desirable fares, expressed in advance of IATA conferences, would carry much more weight than they do at present. These guidelines, while ideally not so rigid as to be binding on the Board when the resultant IATA fare package is submitted for approval, would serve to inhibit American carriers from pursuing goals within IATA markedly at odds with the Board's concept of the public interest. So long as the Board cannot set the American carriers' fares for them, these carriers may continue to acquiesce in unacceptable proposals at IATA conferences. ${ }^{208}$

Would this serve to invoke paragraph (e)? Short of a "compromise" consenting to the jurisdiction of the ICJ or a referral to the ICAO for arbitration, there is no nay of getting an authoritative answer. This in itself would be the cause of much confusion; a compounding problem would be the fact that no real effort to resolve the ambiguity would probably be made until a crisis arose. An additional complication is the fact that. since such legislation would affect virtually all air service bilateral agrcements to which the United States is a party, the ambiguity could not be resolved through negoliations with just one bilateral partner.

207. Cf. Keyes, supra note \%0, at 188-89.

208. The following dialogue is revealing in this respect. Congressman Samuel Devine of Ohio: "In your statement of purpose you say you want to help the U.S. carriers to bring down their rates. : . Do you think they have ever made an effort to brine down the rates without assistance from your Board?" Chairman Alan Boyd of the CAB: "No, sir; I am generalizing here . . . . This could be an unfair statement. Certainly I want to make it very clear that in my judgment Pan American, particularly, has been historically a lowfare advocate on the Atlantic. However, as far as the Pacific is concerned, referring specifically to Pan American and Northwest, who are our two carriers certificated to operate across the Pacific, we are firmly of the opinion that we got a real song and dance routine from those carriers in connection with what was involved in the Ithens Conference last year when we urged them strongly to try to bring about some reductions in the economy-class services across the Pacific." Hearings on H.R. f65, sugra note 89, at 26-27.

The need for some means of public control over the fare positions articulated within IATA may become especially acute if American carriers should come to believe that they must support high fares due to rising labor costs. Anxiety over high American labor costs was recently voiced by the president of Trans World Airlines, see Hearings on $S$. 2f23, supra note 102, at 214, and a senior official of Pan American has stated that primarily because of wage inflation, his company cannot afford to fly as cheaply as some foreign carriers. Interview with John Champion, Senior Director-IATA, Pan American World Airways, Inc., May 5, 1972.

Even if these fears are justified and the American airlines' historic position as low: cost carriers vis-à-vis foreign airlines is being reversed, cost-heavy American carriers should not be allowed to represent solely their own interests at IATA traffic conferences. Permitting American carriers to use the IATA mechanism to preserve their competitive position through inflated fares is tantamount to establishing an industry-operated tariff 
Finally, even if the new law were more responsive to the long-term problem of securing lower fares, it would still be inferior to implementing paragraph (e) powers. The new law invites confrontation. Under the terms of paragraph $(\mathfrak{f})$ resort to sanctions precedes multilateral arbitration. By this retrogressive system of dispute settlement, the swords of sovereign intransigence are allowed to cross. Yet, once blood has been drawn, the likelihood that pleas of international law and public order will be heeded is at its nadir. One has only to review the debates, in press and parliament, which took place in Britain and the United States during the Chandler fare crisis to gain a feeling for how bitter relations can become between otherwise friendly nations when air fares become an issue and paragraph (f) is implemented. ${ }^{200}$ As the mutual sanctions of the parties lead to stalemate, the danger of escalation mounts. Considerations of domestic politics and international prestige may make the issue of air fares recede into the background while jingoism takes hold. The fact that paragraph ( $f$ ) conferred upon the parties a right to take certain actions under international law may be forgotten as the emotions evoked by paragraph (f) sanctions lead to reprisals not authorized by international law..10

Paragraph (e), on the other hand, holds out the promise of peaceful and orderly international dispute settlement procedures. Both paragraphs allow for arbitration under the auspices of ICAO of fare disputes which cannot be settled within IATA or by diplomatic negotiation between the parties. ${ }^{211}$ But the atmosphere of restraint created

commission. Economic protectionism should be a matter of public policy-not private agreement. Furthermore, there is a danger that if they are left untramelled in the posi. tions they take within IATA, the American internntional carriers, with IATA's aid, will make the public pay for management's mistakes. See generally Cordtz, Pan Am's Roulto Across the Sea of Red Ink, ForTuNe, Jan. 1972, at 78.

209. See, e.g., 1 A. ChAYES, ET AL., supra note 59, at $541-49$.

210. For instance, Britain's determination in 1963 to use her paragraph (f) rights of action led her to play somewhat loosely with the language of paragraph ( $($ ). That pro. vision applies only when "one of the Contracting Parties is dissatisfied with any ncw rate proposed by the air carrier or carriers of either contracting Party . . . " Dermutu bilateral, supra note 49 , Annex, $\S$ II, paragraph (f) (emphasis added). This languagc would not seem to allow the British to impound American aircraft for flying at the old rates specified in the expired IATA agreement which the Chandler agreement had becn intended to replace. The issue was complicatd by the fact that the Chandler dispute r(' volved around the amount of the discount to be given for return tickets, not around the base fare upon which the round-trip discount was calculated. Nevertheless, the American carriers proposed nothing new, and asserted a right to keep flying at the old fare and the old discount. It is likely that the British government was aware of the weak legal ground for punitive action against American carriers, but felt that paragraph (f)'s policy of nil tional self-help legitimated belligerent action despite the limitation imposed by a careful reading of paragraph (f)'s text.

211. The arbitral procedure is set out in paragraph (g) of $\S$ II of the Annex to $D$ ('rmuda bilateral, supra note 55. Although the ICAO's response is termed an "advisory re. port," once the CAB obtained paragraph (e) powers, the report would have a mandatory effect on the United States. See note 64 supra. By definition, a Board with paragraph (c) 
by paragraph (e)'s prohibition of sanctions pending arbitration would probably be far more conducive to a mutual submission to arbitration than the belligerent posturing produced by paragraph (f).12

In sum, legislation such as the $C A B$ draft of $S .2423$ would be much more useful in promoting the American public interest and world public order than the amended version of S. 2423 which has become law. The CAB draft would have encouraged lower fares, insured responsible conduct by American carriers, and fostered the peaceful resolution of disputes. Nevertheless, the 1972 amendment to the Federal Aviation Act does serve to end thirty-four years of congressional inertia-the legislative proposals conceived during past air fare crises have all withered in one committee womb or another. The enactment of Pub. $L$. No. 92-259 at least signals congressional willingness to deal with the international air fare regulatory system, and as such bears a promise of more useful legislation to follow.

powers would have the power to prescribe rates for United States' air carricrs, sec note 63 and pp. 1145-46 supra, and so would be bound to set the fare decided upon by the ICAO's arbitral tribunal.

212. The ICAO has heretofore played a very minor role in solving disputes arising under bilateral air service agreements. See $T$. BuERGENTiAal, supra note 43, at 174-97. The combination of (1) initial IATA rate-making responsibility, (2) paragraph (e)'s freedom to inaugurate service at lower rates should IATA's rate-making prove unacceptable, and (3) appeal to the ICAO should any state abuse the low-rate freedom permitted by paragraph (e), would seem to offer both the ultimate political accountability desired by commentators who favor direct inter-governmentad rate-setting, see note 178 supra, and the insulation from day-to-day political disruption which IATA currently affords, cf. note 179 supra. 